POLITE VOCABULARY

IN THE JAVANESE LANGUAGE OF SURABAYA

\begin{abstract}
This paper aims to examine the sociolinguistic situation of the Javanese dialect of the city of Surabaya, East Java, Indonesia with a focus on the polite vocabulary (krama, krama inggil, and krama andhap). Surabaya and its surroundings are known for their peculiar dialect, which does not only exhibit very characteristic phonological and morphological features, but also features understudied pragmatic aspects, especially when it comes to the use of polite, honorific, or deferential terms.

Despite its sounding discourteous to the Central Javanese ear, the Javanese dialect of Surabaya does exhibit politeness, albeit not as refined and not as systematized as in Central Java. A brief typological summary of politeness systems throughout the world in this paper helps determine that Surabayan Javanese can be categorized as a dialect with a T-V distinction rather than as one possessing a speech level system.

This article contains most of what had been presented at the ISLOJ 5 and much of my unpublished master's thesis from 2017.
\end{abstract}

Keywords: Javanese, dialectology, linguistic etiquette, politeness, speech levels, Surabaya 


\section{CLASSIFICATION OF JAVANESE}

Coming from Indonesia's capital Jakarta, Surabaya is the main hub for travel to East Java and onward to Bali or Lombok, with the busiest long-distance bus terminal of Indonesia, the biggest harbour, and the third biggest airport of the country. The Indonesian National Route 1 runs right through the centre of Surabaya and the Trans-Java toll road is supposed to end in Surabaya upon completion. The population of Surabaya is a cosmopolitan mix of the original East Javanese people (wong Jowo or more specifically arèk Suroboyo), the neighbouring Madurese (wong Meduro), and those of Chinese decent (wong Cino or singkèk), who have been settling around Surabaya since the fifteenth century (Rafferty 1984:250). The Arabs (wong Arab) have their own quarter called Ampèl and Western foreigners (londo) now also find their way into the city.

If a circle is drawn around Yogyakarta and Solo, the so-called centres of Javaneseness (kejawèn), Surabaya lies in the eastern periphery. Although the Javanese of Banyuwangi, for example, is spoken a lot further to the east, it is often not classified as a dialect in the periphery, but rather as a distinct language called boso Osing with influences of Balinese.

While East Javanese has been under scientific research for about one hundred years, a surprisingly small number of scholars have focused on the dialect of Surabaya. Apart from very recent works by Tom Gunnar Hoogervorst and Kisyani-Laksono, the only available resources on this dialect are some short treatises and theses written in the Indonesian or Javanese language. These writings are not easily accessible as they are scattered among various university libraries throughout East Java. There is an urgent need to contribute to the recent interest in the dialect of Surabaya with a concentration on lexical and pragmatic aspects such as linguistic etiquette, style, politeness, and lexicology.

This paper is an abridged version of my unpublished master's thesis from 2017 following a one-year stay in Surabaya from August 2014 to September 2015, during which I conducted field research in and around the city. A self-designed questionnaire, appointments with the local TV station JTV, YouTube videos, chats, interlinear glossing of the tentative corpus that arose during my fieldwork, as well as personal interviews with residents of Surabaya have helped me gain insight into the culture and the language of Indonesia's second biggest city. Findings that are presented in this paper have been presented at the ISLOJ 5 in Bandung, in a sociolinguistics seminar in Leiden, in a linguistics course, and as a scheduled talk at the University of Frankfurt.

The spelling used for the Surabaya dialect in this paper is a comprise of a scientific orthography and local conventions as found in the social media. Any / / regardless of its position in the word is spelled "o", and any /a/ is spelled "a". So-called retroflex stops / d/ and / $\mathrm{t}$ that are in fact the alveolar counterparts of the dental stops / $\mathrm{d} / \mathrm{and}$ /t $/$ are indicated by $d h$ and $t h$, respectively ${ }^{1}$. For a discussion on various spellings of Surabayan Javanese throughout the history, see Krauße (2017:28-32).

1 For a discussion on these stops in SuJ, see Kisyani-Laksono (2004a:183-184) and Krauße (2017:22-23). 


\section{CLASSIFICATION OF JAVANESE}

Javanese is the most spoken regional language of Indonesia, outnumbering all other ethnic groups of the country with 69 million native speakers. It is mainly spoken in Central and East Java, including the island of Madura and the northern and easternmost parts of West Java. Javanese belongs to the Malayo-Polynesian branch of the Austronesian language family. Due to the government-driven transmigration program in 1969 (transmigrasi) and the globalization in recent years, Javanese is now also spoken in West Java, Sumatra, Kalimantan, Sulawesi, Papua, and to a smaller degree also in the Lesser Sunda Islands. Beyond Indonesia, Javanese is mainly found in Suriname, New Caledonia, Malaysia, and Singapore.

Within the Austronesian language family, Javanese including all its dialects forms the largest language community. Many attempts have been made to classify Javanese: The language map published by Esser (1938) lists a Malayo-Polynesian group (MaleischPolynesische talen) with a Javanese subgroup (Java-groep) including Sundanese, Javanese, and Madurese. Dyen (1965) was the first scholar to attempt a detailed subgrouping of the Austronesian languages by using lexicostatistical methods. He called one of the subgroups the Javo-Sumatra-Hesion, in which Javanese and Sundanese both made up their own branches, as opposed to the other two main branches of which one was the Malayic Hesion including Malay, Minangkabau, Kerinci, Madurese, and Achinese, and the other being the Lampungic Subfamily including Lampung and Kroë (the latter today being considered a dialect of the Lampung language). Nothofer (1975) attempted to reconstruct Dyen's proto-language of the Javo-Sumatra Hesion but named it Proto-Malayo-Javanic with Javanese as a separate primary branch, the others being the Malay, Madurese, and Sundanese branches. Blust (1981) rejected the inclusion of Javanese and Madurese into the Malayic branch, and instead added other languages such as Minangkabau, Iban and Cham. Consequently, Nothofer (1985:298) provided further evidence for his Malayo-Javanic branch, but also included Lampung and reasoned that Javanese was indeed different from the other languages of this group. A thorough summary of the various attempts at a classification of the Austronesian languages has been published by Malcolm Ross (1995). In his own classification, one of his 24 Austronesian language groups is Java-Bali-Sasak (Ross 1995:74-78). Adelaar (2005a:19-20) excludes Javanese from his proposed Malayo-Sumbawan subgroup and argues that it should be a separate branch of the West-Malayo-Polynesian language group. Evidence for this is presented in another paper (Adelaar 2005b). Adelaar's Malayo-Sumbawan subgroup, however, is rejected by Blust (2010:90; 2013:736). Until today, the classification of Javanese has been a matter of debate.

\section{JAVANESE DIALECTOLOGY}

Javanese is said to have three main dialects and many subdialects (Hadi 1971:6-7; Hatley 1984:6, 24). These three main dialects are Western Javanese, henceforth abbreviated WJ, Central Javanese, abbreviated CJ, and Eastern Javanese, abbreviated EJ. CJ has been the basis of Standard Javanese, henceforth abbreviated StJ. I will use StJ to refer to the Javanese standard used in schools and schoolbooks, and CJ to refer to the dialect used in Central Java (see figure 1). Each dialect group is referred to by the Javanese with various names: WJ is usually called basa Jawa Kulonan or colloquially basa 
ngapak; ${ }^{2} \mathrm{CJ}$ is named basa Jawa Tengah or colloquially basa mbandhèk ${ }^{3}$ by WJ speakers and basa Mataraman ${ }^{4}$ by some EJ speakers; EJ is named basa Jawa Wétanan ${ }^{5}$ or basa arèk'an. $^{6}$ The map below (Hatley 1984:24) shows the geographical distribution of the Javanese dialects.

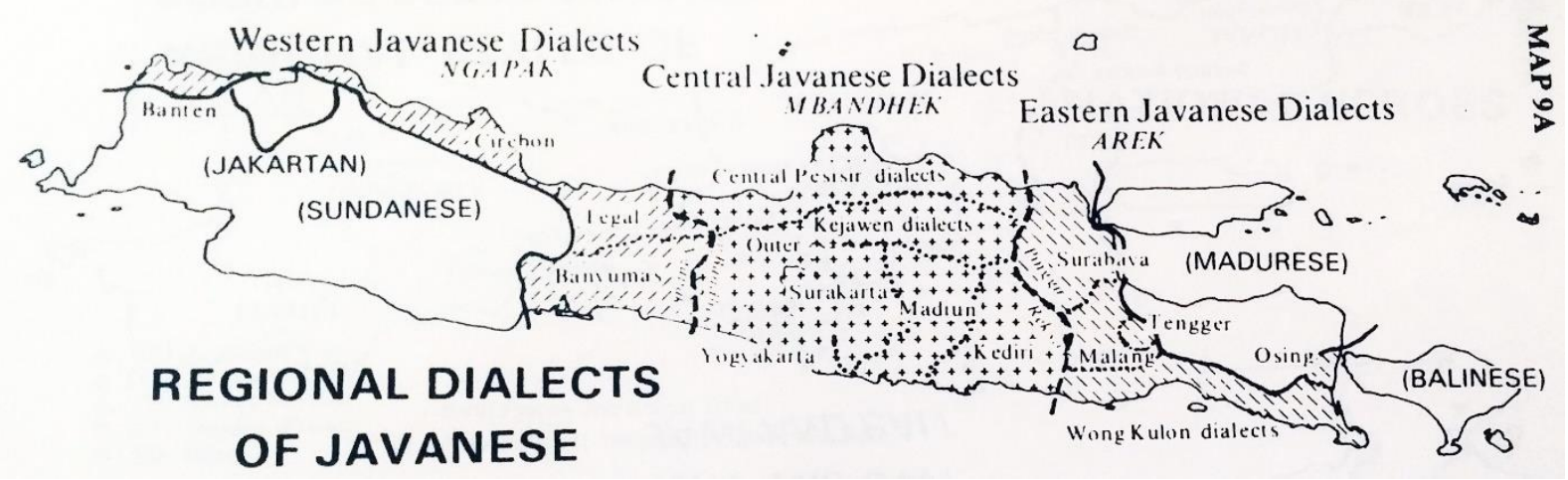

Figure 1: Map of Javanese dialects

Ogloblin (2005:591) reclassifies the main dialect groups as two main branches: the phonologically archaic western group and the central-eastern group with the change from [a] to [0] for final / a/. Conners (2008:26) names these two branches of Javanese "Central" (including WJ and CJ) and "Eastern" (only EJ).

My own research has shown that speakers of EJ do not understand WJ of Banten at all, they have difficulties in understanding the WJ Tegal dialect, while CJ is familiar and comprehensible to them. Kisyani-Laksono (2004a:11) presents similar findings. Unless the EJ speaker grew up using polite $\mathrm{krama}^{7}$ vocabulary, he or she would not be able to follow a high-Javanese conversation from CJ, though. While both the EJ Tengger dialect as well as Osing are generally understood by speakers of Surabayan Javanese (henceforth abbreviated SuJ), some isoglosses ${ }^{8}$ not found in other parts of EJ may slow down the comprehension. Even though Malang Javanese is virtually the same as SuJ

2 This is the colloquial, rather mocking, term used by the CJ and EJ because the interrogative particle apa "what (LL)" is pronounced like [?apa?] in WJ, whereas in CJ and EJ it is [?opo]. The prefix ng- is the agent voice marker for verbs. Thus, the designation basa ngapak means something like "apak-ing language"

3 The word bandhèk has no correspondence in English and is difficult to translate. Various dictionaries give these explanations: "êngg[on-ênggonan], k[rama-]n[goko], ngucapake têmbung Jawa kang aswara a diucapake miring" [regional, high and low level, pronouncing a Javanese word of which the vowel sound a is pronounced in a slanting way] (Poerwadarminta, Hardjasoedarma, and Poedjasoedira 1939:28); "mengutjapkan A (kata Djawa) dengan A bunji miring" [pronouncing the A (in Javanese words) with a slant sound] (Prawiroatmodjo 1957:27); "gwestelijk: het Javaans uitspreken met de a-klank (tegenover de a-klank in Z[uid-]W[est] Midden-Java)" [regional: the Javanese variant that is spoken with the a sound, as opposed to the a sound in Southwest Central Java] (van Albada and Pigeaud 2007:41). The prefixed $m$-is the agent voice marker here. Thus, the designation basa mbandhèk means "language using the / / sound".

4 The term Mataram(an) refers to the Mataram Kingdom (1587-1755), which encompassed all of Central Java and parts of East Java in its Golden Age, but in 1755 was divided into the Surakarta Sultanate under Paku Buwono III and the Yogyakarta Sultanate under Hamengku Buwono I according to the Treaty of Giyanti. People of these two cities are considered to speak the most refined CJ variety today.

5 This term could be translated as "easterly Javanese language".

6 This designation has been applied to the language of East Java because of the ubiquitous use of the term arèk "child, kid, person" instead of the StJ term bocah "child", sometimes even replacing (u)wong "person". This word is probably derived from polite StJ laré "child", compare larèk "child" in the Tuban dialect (Hoogervorst 2008:84, fn. 83). A translation of basa arèk'an could be "arèk-ish language".

7 The designation krama is attested in OJ as krama "conduct, behavior", borrowed from Sanskrit क्रम krama "course, progress".

8 Among these obscure isoglosses to the SuJ speaker are rika "I" for Tenggerese, and sing "not" for Osing. 
and other EJ varieties around it, its reverse speech variant (called osob Ngalam, boso Walék'an or boso Kiwalan ${ }^{9}$ ) is only understood by those who grew up in Malang society. Very few of those words have also found their way into SuJ, for example èbès "father" from dialectal Javanese sèbèh "id." (Yannuar, Iragiliati, and Zen 2017:115), and wóles "relaxed" from English slow (Espree-Conaway 2013:2).

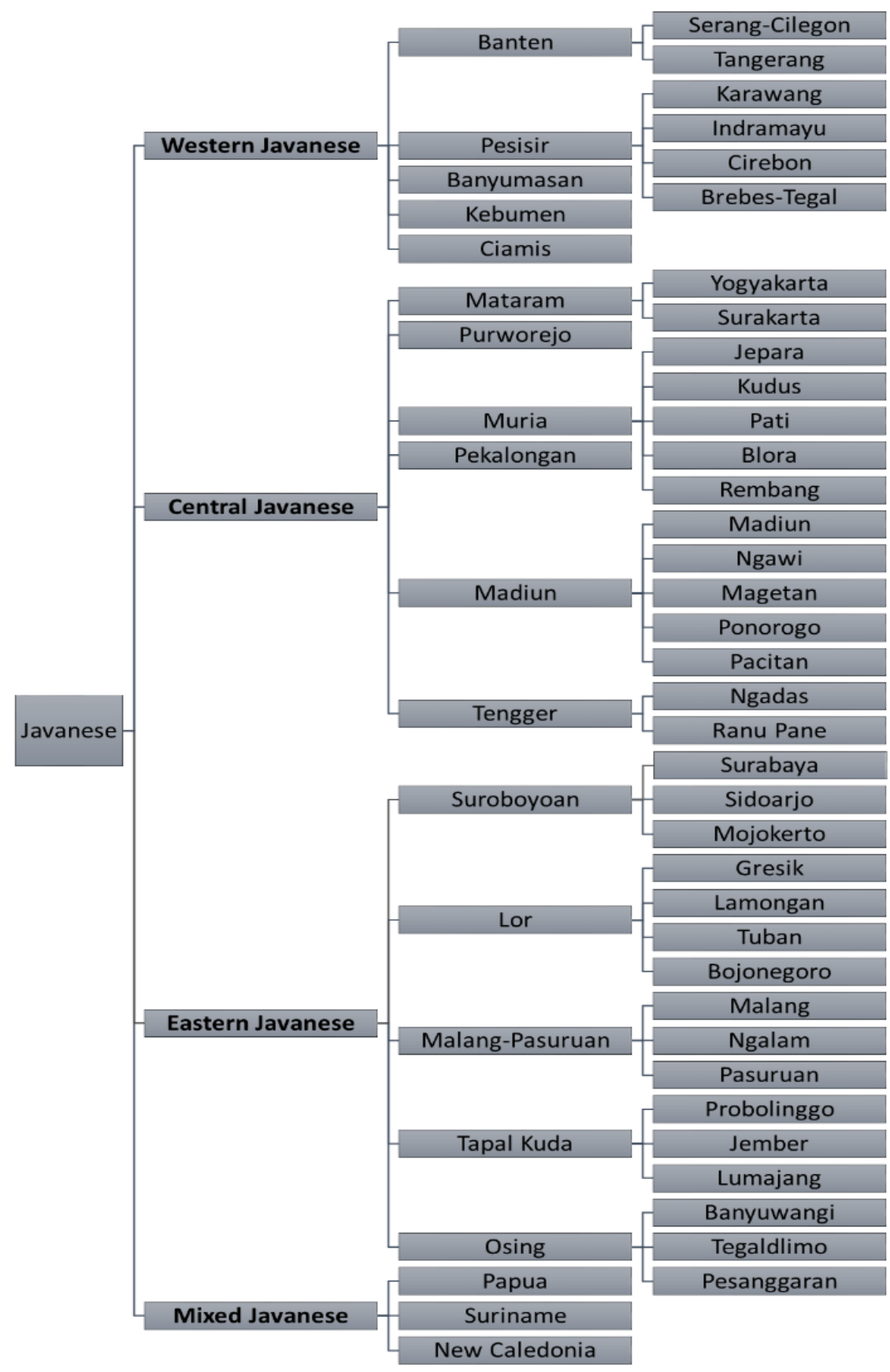

Figure 2: Javanese dialects

The overview of the Javanese dialects in figure 2 is from Krauße (2017:8). Note that the terms Western Javanese, Central Javanese, and Eastern Javanese do not refer to the

9 Osob Ngalam is the reverse reading of boso Malang "Malang language". Boso Walék'an is the Javanese term for 'reverse language'. Osob Kiwalan is the pseudo-reverse word of boso walikan [bo.so wa.le. Pan] "reverse language". For more information on this language variety, cf. Hoogervorst (2009:43-44). 
political boundaries of West Java, Central Java, and East Java but to phonological and morphological differences between these dialects.

Some of the dialects are difficult to classify: Tenggerese, for example, is spoken in the Tengger highlands surrounded by EJ; much of its vocabulary is borrowed from EJ but it is phonologically closer to CJ and EJ. Historically, the dialect originates from CJ. The Madiun dialect chain is spoken in East Java but classified as CJ. The East Javanese regencies Situbondo and Bondowoso are predominantly Madurese with only a very small number of Javanese speakers and are not listed in the classification above.

\section{PREVIOUS STUDIES ON EAST JAVANESE}

Pigeaud (1967:11) admits that almost nothing can be said about the dialects of the preIslamic period. It is, however, well-known that Javanese in West Java was influenced by Sundanese (Pigeaud 1967:12; Nothofer 1980:156-158) , and that Javanese in East Java to the east of the Tengger massif was superseded by Madurese (Pigeaud 1967:12). According to Pigeaud (1967:12), the EJ variant Osing was left untouched by Madurese, however Kisyani-Laksono (2004a:39-41) finds that there has been a considerable influence of Madurese all over East Java. Balinese also had a significant impact on Osing (Kisyani-Laksono 2004a:42-43).

Linguistic study of Javanese in general does not have a very long tradition and thorough study of Javanese dialects does not reach much further back than to the late nineteenth century. According to Uhlenbeck (1964:42), the scientific knowledge of Javanese was very limited up to the beginning of the nineteenth century, and works of that time merely consist of wordlists, seldom containing information on morphology, syntax or linguistic etiquette of the dialects. One of the first chrestomathies of Javanese with explanatory notes on its usage, written entirely in hanacaraka ${ }^{10}$ was Carel Frederik Winter's Javaansche zamenspraken [Javanese conversations], the first volume edited by Taco Roorda (1848), the second volume edited by Salomon Keyser (1858), using the CJ dialect. The large grammar book Javaansche Grammatica [Javanese grammar] (1855) by T. Roorda, also containing a description of the speech level system, was a milestone in early Javanology. Apart from C. F. Winter and T. Roorda, the most famous scholar on Javanese and other Austronesian languages of the nineteenth century was Herman Neubronner van der Tuuk, who strongly opposed Roorda's linguistic views of Javanese (Uhlenbeck 1964:51-53; Grijns 1996:358-359) and noticed lexical discrepancies between StJ and the EJ dialect of Banyuwangi including a list of Balinese loanwords in this dialect (Hoogervorst 2008:9).

Kats' translations of a conversation into various Javanese dialects in his book Serat warna sari Djawi [Book of Javanese collections] (1929) gave rise to new dialectal studies. Mardjana (1933) compared the phonetic and morphological differences of several dialects with each other. Research on EJ did not start until the early twentieth century except for a short essay on the Tenggerese dialect by Kreemer (1885). The MalangPasuruan dialect was first outlined by van Hinloopen Labberton (1900), and has only

\footnotetext{
10 Hanacaraka pronounced ['ho.no.,co.ro.ko], is the name of the native Javanese script and is derived from the Kawi script used for OJ, ultimately a descendant of the Brahmi script of South Asia. Today, its use has heavily declined, and most of the younger Javanese are illiterate in hanacaraka.
} 
been examined again much later by Sudarwati (1987) and recently by Hoogervorst (2014). The reverse speech of Malang, usually called Boso Walikan, has been treated by Suharto (1983), Widodo (2006), Espree-Conaway (2013), Hoogervorst (2014:107-118), and most recently by Yannuar et al. (2017). The adjacent dialect of Surabaya has been studied by Srijono (1976), Soetoko et al. (1984), Sri Budi Astuti (1986), Oetomo (1988), Adipitoyo et al. (1999), Siwidana (2004), Khristarini Mariana (2005), Anggraini (2005), and most extensively by Hoogervorst (2006; 2008; 2009). The relatively isolated people of the Tengger massif between Surabaya and Malang and their unique EJ dialect have been well researched by Smith-Hefner (1983; 1988), Soedjito et al. (1984; 1985), Sutoko et al. (1985), Sunoto (1990), Kisyani-Laksono (1998), and in great detail by Conners (2008). The language varieties further north of East Java around Surabaya, that is Gresik, Lamongan, Tuban, Bojonegoro, and Mojokerto, have been observed by Soegianto (1982), Sunaryo et al. (1984), Soedjito et al. (1986), Kisyani-Laksono (1995; 1999; 2000), and Yulianto (2010). The EJ dialect of Jember has been worked on by Lestari (2012). A short treatise on the EJ variety of Banyuwangi (Osing) was first published by Soediro (1932), and another one by Prijanggana (1957). In the following years, several publications on Osing appeared, for example Soetoko et al. (1981), Mas Moeljono et al. (1986), Sariono (2002), and Kisyani-Laksono (2001; 2004a; 2004b). Kartomihardjo (1981) thoroughly outlined the communicative codes of East Java in general, and other authors have also described several varieties spoken all over East Java, for example Soedjito et al. (1981; 1985), Soedjiatno et al. (1984), Mujianto et al. (1990), and KisyaniLaksono (2004a).

There are only a few dialectal dictionaries available. For the EJ dialects, only Ali's $\mathrm{Ka}$ mus Bahasa Daerah Using-Indonesia [Dictionary of the regional language Using and Indonesian] (2002), Djupri's Kamus Suroboyoan-Indonesia [Surabayan-Indonesian dictionary] (2008), and Soenarno's Kamus bahasa Malangan [Dictionary of the Malang language] (2011) are known to me. All other dictionaries for Javanese are largely based on the standard dialect spoken in Central Java around Yogyakarta and Solo, with dialectal differences as marginal notes. However, the Internet allows private bloggers to publish wordlists of local varieties online on their website.

\section{SURABAYA'S CITY PROFILE}

Surabaya (pronounced / surabaja/ in Indonesian Malay, / surəbə.j / in SuJ) is generally not recommended as a tourist spot in guidebooks. The capital of East Java Province used to be and still is an industrial city, Indonesia's second-biggest metropolis, and usually only known among tourists as the transport hub on their way to Bali or Mt. Bromo 11 . Dick (2002:1) states that "[e]fforts to promote the city as a tourist attraction have been halfhearted and almost embarrassed. [...] For those who just pass through, the city seldom gives rise to fond memories." Most people stay in Surabaya for business or education, not for vacation. In 2010, the total population of Surabaya municipality amounted to 2,765,487 people (Badan Pusat Statistik 2010). Basically, there is

11 Surabaya's Juana Airport is the third busiest of Indonesia with 19,483,844 passengers in 2016 (Surya TRIBUNnews.com 2017), Surabaya's Gubeng train station is the busiest all over East Java with 18,772 passengers in 2016 (BeritaSatu.com 2016), and Tanjung Perak is the biggest port in the country with 206,248 passengers in the first half of 2016 (BeritaTrans.com 2016). 
almost no difference between Surabaya and the adjacent regencies of Gresik and Sidoarjo in terms of culture and language, and the transition from one city to the next is seamless. Its metropolitan area (Surabaya Raya) including Gresik and Sidoarjo spans an area of 2,116.7 square kilometres with a population of 6,484,026 people (in 2010), equalling to a density of 3,063 people per square kilometre. Together with the regencies of Bangkalan, Mojokerto, and Lamongan, the large urban agglomeration is termed Gerbangkertosusila12 (Hermanto 1996) with a total population of more than nine million.

The city of Surabaya lies on the north coast of Central East Java at the Madura Strait of the Java Sea, and thanks to the Suramadu Bridge, the longest bridge of Indonesia opened in 2009 now allows for an easy connection to Bangkalan on Madura Island. The first mention of the region may have been in Zhao Rugua's book 諸蕃志 [Zhū Fān Zhì] in 1225 CE (Wáng Shū Rèn 王叔任 1987:494) as Middle Chinese 戎牙路 nyuwng ngæ luH (Baxter transcription), commonly Romanized as Jung-ya-lu (Hirth and Rockhill 1911:71), which refers to the Kingdom of Janggala. The name "Surabaya" appeared as surabhaya in the Old Javanese eulogy Nägarakrtāgama in 1365 CE$^{13}$, and as çürabhaya on a Trowulan charter in $1358 \mathrm{CE}^{14}$. In folk etymology, its name is generally explained as being from sura "shark" 15 and baya "crocodile", which has lead to Surabaya's emblem of a shark and a crocodile fighting with each other to depict the struggle of life between sea and land (Rouf and Ananda 2013:60-61). This folktale has also inspired the creators of the Culoboyo video clips. Other sources claim that the name is derived from Javanese sura ing baya "brave in danger" (Timoer 1983:14). The real origin of the name remains a mystery.

Surabaya probably became well-known to the west by Kurt Weill and Bertold Brecht's musical "Happy End" in 1929 through the ballad "Surabaya Johnny" (Barber 1985:158159), in which the singer Lilian Holiday describes a short relationship to her unfaithful lover Johnny. Neither the song nor the musical is known among the residents of Surabaya (Lenz 2011).

12 This abbreviation is an acronym for Gresik (with metathesis), Bangkalan, Mojokerto, Surabaya, Sidoarjo, and Lamongan, and may be translated as "Gate to perfect moral" (Malay gerbang = gate; OJ: krta = perfect, prosperous; OJ: susila = virtuous).

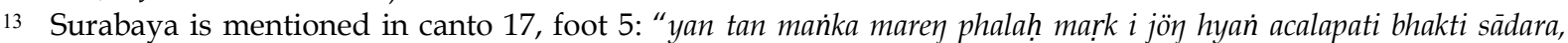

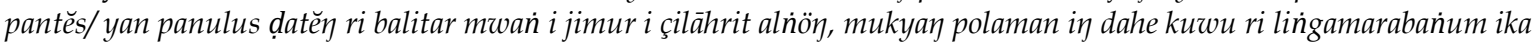
lanenusī, yan/ rì jańgala lot sabhà nrpati ring surabhaya manulus mare buwun." (Pigeaud 1960a:14) [Otherwise he goes to Palah to come into the presence of the divine Lord of the Mountain with devotion and reverence, and it is fitting to go further on to Balitar, to Jimur and to Silâhrit to enjoy the scenery. The main place in Daha is Polaman, and Kuwu and Linggamarabangun he always visits, and when in Janggala the King constantly frequents Surabhaya, and then goes on to Buwun.] Translation by Robson (1995:36).

14 Along with many other rural districts along the River Brantas, Surabaya is mentioned in plate 5 recto, line 4 : “... bukul, $i$ çūrabhaya, muwah prakāraning naditīra pradeça sthānaning anāmbangi i madantěn, $i$ waringin wok, $i$ bajra pura, i ..." (Pigeaud 1960a:110) [... Bakul, Shürabhaya. Also concerning the various rural districts on the banks of the rivers, places of ferrymen in: Madantĕn, Waringin-Wok, Bajrapura, ...]. Translation by Pigeaud (1960b:159)

15 While "shark" (Malay ikan hiu) is the common translation of sura in Surabaya's folktales, this is merely the proper name of the shark character in the folktale. Sura does not mean "shark", but rather "brave", "deity", "hero", or the "first month of the Islamic calendar" (Poerwadarminta, Hardjasoedarma, and Poedjasoedira 1939:575). 


\section{SOCIAL STATUS OF JAVANESE IN SURABAYA}

Hoogervorst (2009:45-54) has comprehensively depicted the sociolinguistic history of $\mathrm{SuJ}$, to which not much can be added. I will therefore briefly summarize what should be said on the historical and the current background of the city of Surabaya along with a description of SuJ's representation in the media. During my fieldwork from 2014 to 2015, I designed a questionnaire to gather information on the current sociolinguistic situation of Surabaya. Some of the results are presented in the following chapters.

As a summary to what was happening with minority languages in Indonesia before the twenty-first century, Hoogervorst (2009:47) states that "throughout the New Order ${ }^{16}$, Javanese in the media remained intertwined with a kind of traditionalism. Most performances were musically enlisted with gamelan and the actors wore traditional Javanese or Madurese clothes, whereas western clothes and music were associated with Bahasa Indonesia, the language of modernism and public discourse.". Javanese was the language at home, in the streets, but it was improper for education, politics, or broadcasting. The few Javanese songs that were composed during that time were sung in the traditional kendhang kempul style while Indonesian songs had a western touch. One of the most famous songs in the dialect of Surabaya was Rèk, ayo, rèk.

The Kongres Bahasa Jawa [Congress of the Javanese Language] was first held in 1991 in Semarang, since then every five years in Malang, Yogyakarta, and Surabaya. Some of their topics have also dealt with Javanese linguistics and dialectology. The Balai Bahasa Surabaya [House of Surabaya's Language], situated in Sidoarjo, was established in 2001 and has been trying to raise awareness among the East Javanese community for their language, with moderate success. Only in the last few years, SuJ has become a dialect used in all kinds of mass media.

According to my survey among 165 residents of Surabaya (73\%), Gresik (13\%), Sidoarjo $(13 \%)$, and other places $(1 \%)$ with more than a half of them aged between 15 and 20 , a total of $86 \%$ stated that they were fluent in Indonesian Malay, $81 \%$ said they were fluent in low level SuJ, while only $29 \%$ could communicate in high level SuJ (multiple answers allowed). Fluency of CJ lies at around 6\% in Surabaya. The survey showed that $77 \%$ of all respondents use Indonesian Malay at home, 52\% use low level $\mathrm{SuJ}$, and only $34 \%$ employ high level SuJ (multiple answers allowed). About $7 \%$ state that they speak a mix of the languages at home. For counting basic numbers, $72 \%$ stick to Indonesian Malay, half of the respondents would count in low level SuJ but only 9\% use high level SuJ, while $14 \%$ state that it depends on the situation which language or register they use for counting. $88 \%$ of the respondents use $\mathrm{SuJ}$ among friends, $57 \%$ within the core family, $34 \%$ with people in their hometown, $26 \%$ with villagers of East Java, $20 \%$ within the broad family, and only $6 \%$ with their teachers.

These numbers confirm the assumption that minority languages and especially dialects are virtually never used in educational institutions and are reserved for close friends, the family, and people whose Indonesian Malay may not be sufficient enough to hold a fluent conversation. There is a clear tendency that the more formal the situa-

\footnotetext{
16 New Order (Orde Baru) is a political term to refer to Suharto's regime (1966-1998) when Indonesia experienced an economic boom and the national language Indonesian was promoted through a massive language planning program.
} 
tion is, the more likely Indonesian Malay is preferred over SuJ. In very informal settings, Indonesian Malay is only sporadically employed with SuJ being the dominant language, whereas in education or politics $\mathrm{SuJ}$ is inappropriate with Indonesian Malay being considered adequate. In a few religious contexts, $\mathrm{SuJ}$ is preferred over Indonesian Malay. According to my own experience, many villagers in East Java are able to understand Indonesian Malay very well but they would only answer in their EJ dialect or in Madurese. However, these people are also very likely to use the high level register whereas it is on the decline in urban communities.

\section{SURABAYAN JAVANESE IN THE MEDIA}

The Javanese dialect used in Surabaya is not limited to communication between family members and friends, but is found everywhere in and around the city. One could even say that it is one of the most prominent dialects of any regional language in Indonesia. Non-residents of Surabaya are often well aware of how SuJ sounds like, and they call it a very rude language. One of the slang words known all over Indonesia is jancók ${ }^{17}$, referring to anything negative similar to English "damn", "hell", or "fuck", but may also be used as a discourse marker between very close friends.

There are a handful local TV stations in Surabaya (TVRI Surabaya, SBO TV, JTV Surabaya, RTV Surabaya, Kompas TV Surabaya, Bios TV, MHTV Surabaya), however only one regularly broadcasts news and entertainment in SuJ, namely private-owned JTV Surabaya ${ }^{18}$. The most popular programs broadcasted entirely in SuJ are the newscast Pojok Kampung [Neighbourhood corner] ${ }^{19}$ with nearly no polite vocabulary, the entertainment program Blakra'an [Sauntering] with very high level vocabulary, B-Cak Show [Rickshaw Show] ${ }^{20}$ with virtually no vocabulary of the high level, the comedy show Ndoro Bèi [The Master] ${ }^{21}$, the theatre-like staged show Goro-Goro Kartolo with much of the conversations considered very polite in Surabaya, and another theatre-like staged show Ngethoprak Kirun [Kirun performs on stage] ${ }^{22}$ with little high level conversations. Apart from those based in Surabaya, Arek TV from Sidoarjo also broadcasts shows in $\mathrm{SuJ}$ every now and then, and JTV Malang offers shows in Malang Javanese, which is very similar to SuJ. Much of my SuJ material has been taken from JTV news and entertainment.

17 This word is probably a contracted from of diancuk, the patient voice form of ancuk "to fuck, to copulate with".

18 JTV stands for for Jawa Timur Televisi “East Java Television" and belongs to the Jawa Pos TV network owned by Jawa Pos Group.

19 The translation is not accurate, but there is no English word for kampung. In Indonesia, the word describes smaller settlements within a big city, often with narrow and crowded alleyways, resembling the traditional life before globalization. The term may also be used to refer to people who are less likely to access education and are often taught at home or through religious institutions. Pojok Kampung has been chosen for the TV program to relate to the language spoken in those settlements where dialectal Javanese is often preferred over the national language Indonesian.

20 The abbreviation $b$-cak is read bècak "rickshaw" but the spelling $b$-cak suggests a combination of Javanese bareng "together (with)" and the SuJ title cak "mister", as the show is about two men discussion various topics using SuJ.

21 Ndoro is the short form of StJ. bendara "master, mistress, sir" and bèi is shortened from ngabèhi "an official of middle rank in court hierarchy" (Robson and Wibisono 2002:506).

22 The term ngethoprak is the active voice verb of kethoprak "Javanese popular drama depicting historical or pseudohistorical events" (Robson and Wibisono 2002:369) and Kirun is an old-fashioned name. 
YouTube, Twitter, Facebook, and weblogs have become the ideal medium to broadcast entertainment in the local dialects. Among the most famous YouTube stars speaking entirely in Malang Javanese is 23-year-old Bayu Skak, his real name being Bayu Eko Moektito. Although being a native speaker of Malang Javanese, he virtually never uses the reverse speech of Malang and is therefore easily understood by anyone around Malang, including Surabaya. Another famous YouTuber using SuJ is the Australian citizen Dave Jephcott, better known as Londo Kampung19 "neighbourhood foreigner", who has been living in Surabaya since the age of two (Supriyanto 2017). Mohammad Sholikin, better known as Cak Ikin, has been using YouTube as a platform to publish his animated videos under the name Culoboyo Juniol "Junior Surabaya" (in EJ child language) since 2007 onward (Junita 2016). Several other animated videos also appeared under similar names, but with the two main characters, Culo the shark and Boyo the crocodile.

The only printed media making use of SuJ are Jaya Baya (old spelling: Djaja Baja) and Panjebar Semangat (not changed after the spelling reform in 1972). A few authors are known to have published their works in the local dialect of Surabaya, among them Sri Setyowati alias Trinil and Budhi Santoso. Trinil's books are composed entirely in SuJ; her most famous one being Donga kembang Waru (2004). Santoso's most popular work is Humor Suroboyoan (three volumes) with many conversations in SuJ.

$\mathrm{SuJ}$ is also sporadically found in traffic announcements throughout Surabaya. At the intersection of Jl. Raya Darmo/Jl. Raya Diponegoro, the city has installed a traffic light making announcements in SuJ. Although the addressees are mostly elderly people, all words used belong to the low level vocabulary. Public speeches in Surabaya, especially those on religious affairs before the Hajj season, are often held in SuJ. This is one of the few instances where high level SuJ can be heard as the low level is improper for actions referring to God or the Prophet.

There have been some songs recorded entirely in SuJ and adjacent dialects, of which the most popular one is Rèk, ayo, rèk "Guys, c'mon, guys" sung by the Surabayan native Mus Mulyadi but composed by the CJ songwriter Alphonsius Is Haryanto. Bayu Skak sings in Malang Javanese.

\section{POLITENESS STRATEGIES IN JAVANESE AND OTHER LANGUAGES}

A lot has been written on Javanese linguistic etiquette by Poedjosoedarmo et al. (1979), Kartomihardjo (1981), and Errington (1988). However, I will first explain how linguistic etiquette is lexically expressed in various languages around the world and how this relates to $\mathrm{SuJ}$.

Basically, all human languages have the possibility to express politeness. It may therefore be called a language universal (Brown and Levinson 1978). Each conversation requires some form of etiquette, the customary code of polite behaviour in dialogs, telephone calls, TV shows, talk shows, instructions, reports, introductions, letters, dramas, announcements, the social media, etcetera. In scientific papers or neutral newspaper articles, this etiquette is generally not required if no one is directly addressed. This dialogicity is based on the binary speaker-listener constellation in a current speech situation (Lee 1996:109), usually expanded by the third (personal or impersonal) party 
that is being talked about, as has been explained by Bühler in his organon model (1934), later expanded by Jakobson (1960) and subsequently newly structured and organized by Schulz von Thun (1981).

Languages approach the concept of these three sides of communication (speaker, listener, topic) differently: by gestures and facial expressions; by intonation or prosody; by passivation, impersonalization, or the change of grammatical mood; by paraphrasing, negation or interrogation; by polite affixes or suppletive lexemes marked for politeness or social class; and by capitalization.

Below is a summary of how politeness is marked in the world's languages, similar to what has been observed by Helmbrecht (2013). There are five types of politeness strategies, not including avoidance speech as found in some Australian, African, North American, and Caucasian languages. The typological classification is necessary to determine which system is used in $\mathrm{SuJ}$.

In most languages, politeness is grammatically covert, that is the language does not have an obvious system of marking the linguistic etiquette within the context in which the utterance is made. Although there may be ways to choose a word of a different register to speak more politely, it is not a paramount part of its grammar. Politeness and deference is therefore rather expressed by conversational and conventional implicature (Grice 1975) or by terms of address such as "Mister/Mistress/Sir" or kinship terms. Languages that belong to this type are Modern English, the $\mathrm{Kx}^{\prime} \mathrm{a}$ languages, all indigenous languages of North America and Australia ${ }^{23}$, and some languages of the Caucasus such as Ossetic. Irvine (1998:54) asserts that many Bantu languages also exhibit respect forms locating them in the morphology of the noun classification system.

Many languages of Europe employ a so-called T-V distinction in the pronominal system for the addressee (Brown and Gilman 1960). Friends, family members, children, and deities are usually addressed with the non-polite T-pronoun (from Latin $t \bar{u}$ ) while older people, highly esteemed persons, and strangers are spoken to using the polite $\mathrm{V}$ pronoun (from Latin $v \bar{s}$ ). Languages with this feature are European French, European Spanish, German, Dutch, Russian, Serbo-Croatian, Modern Greek, Welsh, Estonian, Turkish, Basque, etcetera. There are also languages outside of Europe with this binary distinction, such as modern Mandarin, Armenian, Modern Standard Arabic, and Yoruba. One may say that these languages mark politeness or respect overtly by employing a clear and well-defined set of pronouns either referring to the non-polite, informal or to the polite, formal register, respectively. In the following chapters, I will show that $\mathrm{SuJ}$ as used by younger speakers may be considered a dialect having a $\mathrm{T}-\mathrm{V}$ distinction, which is rather unusual for the languages of Southeast Asia. However, it is noteworthy that $\mathrm{SuJ}$ had never developed a speech level system as thoroughly as CJ due to Surabaya's location in the outer periphery from the political centres of Yogyakarta and Surakarta at the time when the Javanese speech levels emerged. The lack of a speech level system in SuJ yields fear among its speakers to use their mother tongue in areas where the classical speech level system is still prominent. Absence or near-absence of speech levels in dialects of languages that are known for their speech level system are rare,

\footnotetext{
23 Avoidance speech is not regarded as a politeness system here. One might even say that languages that employ an avoidance style system contrast with those that have an elaborate politeness system. Thus, there are basically two kinds of sociolinguistic address systems, and most languages only possess one, if at all.
} 
but also occur in the Banten dialect of Sundanese and Javanese, and the Kansai dialect of Japanese.

Especially the languages of South Asia make use of an overt, grammaticalized system of politeness, usually determined by social hierarchy based on age, profession, rank, prestige, or title (Fritz 2005). There are usually at least three levels of linguistic etiquette in the pronouns: the first being neutral or intimate and is used among close friends and family members; the second is respectful used with people of higher social status; and the third is highly honorific for teachers or clerics. This may be marked in different 2SG and/or 2PL pronouns or with a term of address, while the verb is usually used in its plural form if the language has verbal inflection for grammatical number. Languages that possess such politeness systems are Hindi, Marathi, Malayalam, Nahuatl, Persian, and to some extent Hungarian, Tagalog, formal Malay, but also Bemba of Zambia.

The politeness system used in many languages of Southeast Asia and East Asia, such as Burmese, Vietnamese, Thai, Lao, Khmer, Sinhala, and Classical Chinese is more refined than that of South Asia in that speakers of these languages choose their words and especially pronouns carefully to express appropriate politeness. The high number of pronouns in these languages allows for a very specific speaker-listener classification in the social hierarchy. For Thai, Kummer (1992:331-332) gives eight possibilities for the 1SG and nine for the 2SG pronouns with eight other pronouns depending on the conversation. Royal and clerical pronouns, though, are missing in his overview. In languages of this type, any pronoun may be dropped to avoid offense that may result from the choice of the wrong register. Aside from the richness in pronouns, also affixes, verbs and nouns inherently pertaining to a certain register are used to classify the speaker, the listener and the person whom the conversation is about according to social hierarchy.

The fifth system is only found in a very limited number of languages. The politeness system of these languages is the most complex of all as it highly depends on the social status of all interlocutors. In most cases, the polite or honorifics forms are lexically different from their non-polite counterparts. It is possible to speak very politely in an informal context, and it is not uncommon to apply different lexemes for the same action with the same meaning when the interlocutors are of different statuses. Instead of speaking of politeness, this system is generally referred to as speech levels. I suggest that in languages allowing lexeme variation according to the speech level, words that are identical in syntax and meaning but different in their pragmatic function shall be called register allolexes ${ }^{24}$, based on similar concepts, such as allophones (a variation of a phoneme) and allomorphs (a variation of a morpheme). Speech levels in these languages constitute a system that shows the degree of formality and the degree of respect felt by the speaker toward the addressee. To explain the speech level system, I propose the following scheme:

24 The term allolex is sometimes used for the various word forms pertaining to one lexeme in natural semantic metalanguage (NSM), that is I and me of the concept 1SG, -one and -body of SOMEONE etcetera (Wierzbicka 1996:26). However, I adapt this terminology and expand it to register allolex to avoid confusion with the NSM terminology but at the same time emphasize the conceptual proximity to it. 
Table 1: Speech levels in a typological view (Krauße 2017:60)

\begin{tabular}{l|l|l|l} 
Name & Description & Usage & Glossing $^{25}$ \\
\hline Level -1 & Impolite & Very low level; slang; among close friends; rarely used by old speakers & SL \\
\hline Level 0 & Non-polite & Neutral level between friends, peers, and older person to younger one & LL \\
\hline Level 1 & Middle & Slightly polite level in order not to lose face ${ }^{26}$ & ML \\
\hline Level 2 & High & Polite level used with older, superior, exalted, and respected persons & HL \\
\hline Level 3 & Court & Highly polite level only used for the royalty, the emperor, or the sultan & HHL \\
\hline Level A & Honorific & Emphasis is put on the high, esteemed position of the addressee & HON \\
\hline Level B & Deferential & Emphasis is put on the low, humble position of the speaker & DFR
\end{tabular}

Note that not all languages or dialects of this category exhibit all these levels, and some languages or dialects may have additional sublevels. Yet, it is typical for these languages to have native names for all possible speech levels. Languages using this system are Dhivehi, especially the dialect of Male (Fritz 1993:28-29; Fritz 2005:119-122), Lhasa Tibetan (Agha 1993), Japanese (Martin 1964; Coulmas 1992), Korean, Madurese, Sundanese, Balinese, Sasak and Javanese, the latter five being adjacent languages of the Indonesian islands Java, Madura, Bali, and Lombok. The languages to the west (Betawi, Lampung, Abung, Bengkulu) and to the east (Sumbawa, Bima) do not possess such refined speech levels. Madurese, Sundanese, Balinese, and Sasak borrowed their speech level system and the majority of high level vocabulary from Javanese. A general subdivision of the speech levels is threefold: low, middle, and high. In some languages of this category, an additional system denoting deferential (DFR) or honorific (HON) attitude exists. This latter system is then combined with the speech levels.

The five languages of Indonesia differ from the other four languages of this category in that they not only have register allolexes for all pronouns and verbal affixes, but also for many nouns, adjectives, colour terms, verbs, numerals, adverbs, and particles. The most complex and most refined speech level system is found in CJ called unggahungguhing basa "etiquette of language". The Javanese politeness system has been thoroughly described by Uhlenbeck (1950), Horne (1974), Djajengwasito (1975), Soepoma and Koendjono (1976/1977), Poedjosoedarmo et al. (1979), Wolff and Poedjosoedarmo (1982), Smith-Hefner (1983), and Errington (1985; 1988; 1998).

Some scholars or teachers talk about two speech levels (ngoko being the low one and basa the high level) with several subgroups for each level (Errington 1988; 1998), others divide them into the three speech levels low (ngoko, glossed LL in this paper), middle (madya, glossed ML), and high (krama, glossed HL), with at least three subgroups per level as explained in the chart below (Poedjosoedarmo et al. 1979:13). The usage notes in the chart below are mainly taken from Horne (1974:xxxii-xxxiii). A discussion on the basa kedhaton or basa bagongan "court language" (Errington 1982) and on the elaborate literary basa rinengga "decorated language" is not part of this paper, nor will I discuss the StJ speech levels in detail. This has been done extensively in the given literature.

25 Glossing abbreviations used in this paper are the following: APPL = applicative; $\mathrm{AV}=$ agent voice; $\mathrm{DFR}=\mathrm{defer}-$ ential; GEN = genitive; $\mathrm{GEO}=$ geographical term; $\mathrm{HL}=$ high level; $\mathrm{HHL}=$ very high/court level; $\mathrm{HON}=$ honorific; $\mathrm{LL}=$ low level; $\mathrm{ML}=$ mid level; $\mathrm{NEG}=$ negative particle; $\mathrm{NMZ}=$ nominalizer; $\mathrm{PN}$ = proper noun; $\mathrm{PV}=$ passive voice; $\mathrm{REL}=$ relativizer; $\mathrm{SL}=$ slang; $\mathrm{SUBO}=$ subordinator.

26 This term has been extensively discussed by Brown \& Levinson (1978:66-69). 
Table 2: Speech levels of Standard Javanese

\begin{tabular}{|c|c|c|}
\hline Speech level & Sublevel & Usage \\
\hline \multirow{3}{*}{$\begin{array}{l}\text { Krama } \\
\text { (level 2) }\end{array}$} & Mudha krama & $\begin{array}{l}\text { The most refined style with krama vocabulary only, krama inggil is used } \\
\text { when the interlocutor is addressed }\end{array}$ \\
\hline & $\begin{array}{l}\text { Kramantara / } \\
\text { Krama lumrah }\end{array}$ & The most refined style with krama vocabulary only, but no krama inggil \\
\hline & Wredha krama & $\begin{array}{l}\text { Less formal variety of kramantara with occasional ngoko affixation; used } \\
\text { with someone whose status is socially lower but with whom ngoko } \\
\text { would not be appropriate }\end{array}$ \\
\hline \multirow{3}{*}{$\begin{array}{l}\text { Madya } \\
\text { (level 1) }\end{array}$} & Madya krama & $\begin{array}{l}\text { Madya vocabulary is used where available, otherwise krama words with } \\
\text { ngoko affixation and krama inggil terms where appropriate; often used } \\
\text { in the first encounter of a stranger whose status is not obvious }\end{array}$ \\
\hline & Madyantara & $\begin{array}{l}\text { Madya vocabulary is used where available, otherwise krama words with } \\
\text { ngoko affixation }\end{array}$ \\
\hline & Madya ngoko & $\begin{array}{l}\text { Madya vocabulary is used where available, otherwise ngoko words are } \\
\text { preferred over krama words }\end{array}$ \\
\hline \multirow{3}{*}{$\begin{array}{l}\text { Ngoko } \\
\text { (level 0) }\end{array}$} & Basa antya & $\begin{array}{l}\text { Conversation is held in low level vocabulary, but krama words are used } \\
\text { every here and then; used with respected persons in an informal setting }\end{array}$ \\
\hline & $\begin{array}{l}\text { Ngoko andhap: } \\
\text { Antyabasa }\end{array}$ & $\begin{array}{l}\text { Conversation held in low level vocabulary, but krama inggil terms are } \\
\text { used when the respected interlocutor is addressed }\end{array}$ \\
\hline & $\begin{array}{l}\text { Ngoko andhap: } \\
\text { Ngoko lugu }\end{array}$ & $\begin{array}{l}\text { Basic level with no vocabulary of other levels except for krama inggil; } \\
\text { usually used with close friends, younger siblings }\end{array}$ \\
\hline
\end{tabular}

As for an illustration of the chart and the usage of these nine levels, see Poedjosoedarmo et al. (1979) and Krauße (2017:65-68).

Horne (1974:xxxii) estimates that the krama vocabulary has around 850 lexical items, krama inggil around 260, and the madya vocabulary may be around 35 . However, the Javanese corpus available from the SEAlang Library ${ }^{27}$ based on Robson's and Wibisono's Javanese-English dictionary (2002) lists 1612 words for krama, 446 for krama inggil, 61 for madya, and 15 for krama andhap.

Even though many terms of the high level in Javanese can be etymologically traced back to OJ, speech levels were not present in OJ (Ogloblin 2005:591). In fact, common honorific titles were used in OJ, for example san " person of a certain rank", ki/kya "male (usually elderly or revered) person", kyayi "person of some distinction or respectability", and kaka "elder brother or sister, addressing an older person or the husband" (Zoetmulder 1982), but speech levels as in modern Javanese did not exist. Absence of speech levels in OJ also becomes obvious from the fact that the Tenggerese, who after the fall of the Majapahit Empire in the fifteenth century fled from Islamization into the highlands west of Malang called Tengger massif (Conners 2008:28), speak an isolated archaic variant of CJ without krama vocabulary (Adelaar 1989:318). Wolff and Poedjosoedarmo (1982:9) speculate that the origin of speech levels may be found in Southern India, which would also correspond to Emeneau's (1980:12-13) idea of a Southeast Asian-South Indian linguistic area, but this view is generally rejected today (Clynes 1994:158).

The distinction between the normal language called ngoko and the language of courtesy referred to as krama had probably not been established until the sixteenth century with the Sultanate of Mataram (Fox 2005:102), which had its political centre in Kotagede, today's Yogyakarta. Surabaya was captured by the Sultanate of Mataram in

27 Available online at: http:/ / sealang.net/java/dictionary.htm. 
1625, after which Mataram controlled almost the whole of Java and Madura except for the Sultanate of Banten and Batavia (Drakeley 2005:31). It was only then when the speech level system found its way into East Java, however only to a very limited extent compared to the amount of high level vocabulary in Central Java.

\section{THE CASE OF POLITE VOCABULARY IN THE JAVANESE LANGUAGE OF SU- RABAYA}

The language of Surabaya has a reputation of bluntness and rudeness known all over Java and beyond, often called blak-blak'an "frankly speaking". This is the reason why many speakers of SuJ avoid their language outside of East Java. They fear that they may offend speakers of other Javanese dialects and thus switch to Indonesian Malay, which does not possess a speech level system. However, residents of Surabaya are by no means impolite or rude. Examples in this chapter show how politeness works in $\mathrm{SuJ}$.

Among the residents of Surabaya, the high level is often called alus "refined", kromo "high level language", sometimes even kromo inggil "elevated high level language" or kawi "classical Javanese", whereas the low level is referred to as kasar "rude" or ngókó "low level language". In this paper, I have been using the terms ngókó "normal" for the plain vocabulary of $\mathrm{SuJ}$, alus for the polite one, kromo inggil only for terms that elevate the addressee's status, and kromo andhap for terms that lower the speaker's status. Throughout my research, I have come across only a very few alus terms in my corpus compared to the number of krama and krama inggil in StJ.

The following passage 0 from the TV program Pojok Kampung illustrates why SuJ speakers are often regarded as speaking improperly. A translation into CJ reveals the non-polite vocabulary used in SuJ even though the text is about a highly-esteemed member of the military.

(1) Surabayan Javanese

\begin{tabular}{|c|c|c|c|c|c|c|c|c|c|}
\hline \multirow{2}{*}{$\begin{array}{l}\text { Tapi } \\
\text { but } \\
\text { curiga } \\
\text { sceptical }\end{array}$} & $\begin{array}{l}\text { matèk'-é } \\
\text { dead-NMZ }\end{array}$ & $\begin{array}{l}\text { korban } \\
\text { victim }\end{array}$ & $\begin{array}{l}\text { séng } \\
\text { REL }\end{array}$ & $\begin{array}{l}\text { gak } \\
\text { NEG }\end{array}$ & $\begin{array}{l}\text { lumrah } \\
\text { natural }\end{array}$ & \multicolumn{2}{|c|}{$\begin{array}{l}\text { ng-garak-no } \\
\text { AV-make-APPL }\end{array}$} & $\begin{array}{l}\text { bójó-né } \\
\text { spouse-GEN }\end{array}$ & $\begin{array}{l}\text { kor } \\
\text { vic }\end{array}$ \\
\hline & $\begin{array}{l}\text { nèk } \\
\text { SUBO }\end{array}$ & $\begin{array}{l}\text { korban } \\
\text { victim }\end{array}$ & $\begin{array}{l}\text { di-anioyo } \\
\text { PV-torture }\end{array}$ & & $\begin{array}{l}\text { ambèk } \\
\text { by }\end{array}$ & $\begin{array}{l}\text { anggota } \\
\text { member }\end{array}$ & \multicolumn{3}{|c|}{$\begin{array}{l}\text { Kodim. } \\
\text { Military.District.Command }\end{array}$} \\
\hline $\begin{array}{l}\text { Lamongar } \\
\text { PN.GEO }\end{array}$ & & dead & & & & & & & \\
\hline
\end{tabular}

(2) Central Javanese

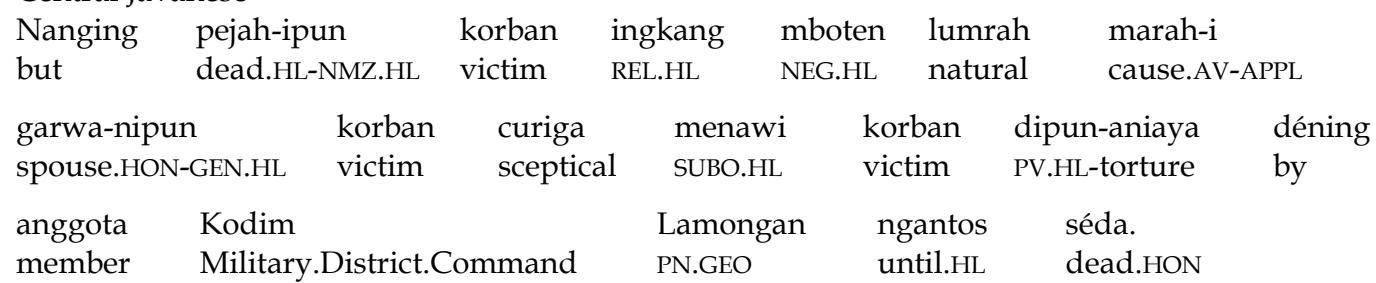

"However, the victim's unnatural death made his wife sceptical that the victim might have been tortured to death by a member of Military District Command of Lamongan."

As can be seen from the example above, no word in SuJ shows politeness, although older people would probably prefer to use sèdo "dead (HON)" instead of the dialectal matèk "dead". In CJ, instead, eight morphemes show politeness and two words are 
taken from the honorific level. The words pejah "dead (HL)", menawi "if, that (HL)", and ngantos "until (HL)" as well as the affixes -ipun and dipun- are virtually unheard of in Surabaya. However, the relativizer ingkang, the negation particle mboten, and the honorific séda are still used in very polite conversations among older people in Surabaya (the latter being pronounced sèdo).

It is very common to combine low level affixes with high level roots in SuJ, for example dibeto "carried" (StJ: dipunbekta), diparingaken "given" (StJ: dipunparingaken), naminé "his/her/the name" (StJ: naminipun ${ }^{28}$ ), sanjangé "he/she says" (StJ: sanjangipun). The combination of low level affixes and high level roots reminds of madya. In fact, the high level of SuJ often corresponds to CJ madya with krama inggil terms.

\section{NON-POLITE VOCABULARY CORRESPONDING TO STANDARD JAVANESE KRAMA}

Very few words that are used in low level SuJ correspond to StJ high level vocabulary. In my corpus of nearly 13,300 words, I have come across wulan "month" 18 times, always in a low level conversation, whereas the StJ low level lexeme sasi "month (LL)" does not appear in Surabaya. Yet, according to my survey, 73\% consider wulan to be high level, 13\% regard it as low level, and 14\% could not decide.

$\mathrm{SuJ}$ speakers use klopo "coconut" as plain vocabulary while it is high level in StJ, the low level form being krambil in StJ. Interestingly, SuJ has krambil for the high level. The high level dialectal form kecambil given by Hoogervorst (2008:33) was unknown to my $\mathrm{SuJ}$ informants.

Another word of this kind is numpak "to ride", which has no high level connotation among SuJ speakers. According to various dictionaries (Poerwadarminta, Hardjasoedarma, and Poedjasoedira 1939:348; Horne 1974:670; Harjawiyana and Supriya 2001:289), the StJ low level form is nunggang "to ride" (LL) with numpak being the high level and nitih the honorific allolex, but my CJ informant from Yogyakarta asserted that numpak is also used in low level conversation with nunggang being a synonym of it. Robson and Wibisono (2002:765) classify numpak both as a low level variant of nunggang and as high level of it.

\section{POLITE VOCABULARY CORRESPONDING TO STANDARD JAVANESE KRAMA}

As already stated previously, the number of StJ krama amounts to about 1,600 lexemes. However, I have only come across 84 high level words in SuJ that correspond to StJ high level. Those that I have encountered are listed below; words marked with a cross $\left(^{\dagger}\right)$ are very rare in $\mathrm{SuJ}$ and are usually not understood by most younger speakers, leaving a rest of 63 alus terms understood by them.

28 The form naminipun is rarely used in StJ or CJ because nami (or alternatively nama) refers to oneself, for example nami kula "my name", and is therefore usually not affixed with -(n)ipun for the third person. The common expression in StJ would be asmanipun "his/her/the name" with asma being the honorific allolex of nami (HL) and jeneng (LL). In Surabaya, naminé "is prevalent, though. 
Table 3: Surabayan Javanese high level corresponding to Standard Javanese high level vocabulary

\begin{tabular}{|c|c|c|c|}
\hline $\begin{array}{l}\text { SuJ low level } \\
\text { (ngókó) }\end{array}$ & $\begin{array}{l}\text { SuJ high level } \\
\text { (alus) }\end{array}$ & $\begin{array}{l}\text { StJ high level } \\
(\text { krama) }\end{array}$ & $\begin{array}{l}\text { translation } \\
\text { (English) }\end{array}$ \\
\hline akèh & kathah & kathah & much, many, a lot \\
\hline aku & kulo & kula & $\mathrm{I}, \mathrm{me}$ \\
\hline aran & nami & nami & name, designation \\
\hline arèk & larét & laré & child, person \\
\hline arep & badhé & badhé & FUT \\
\hline ati-ati! & atos-atos! & atos-atos! & take care! \\
\hline ayók & monggo & (su)mangga & as you wish, please \\
\hline cilik & alét & slit & small \\
\hline dadi & dados & dados & to become, to be \\
\hline balék & wangsul & wangsul & to go back, to return \\
\hline dhuék & arto & arta & money \\
\hline dhukór & (ng)inggil† & inggil & high, tall, upper \\
\hline dino & dinten & dinten & day \\
\hline (n)dué & (ng)gadhah & gadhah & to have \\
\hline dóróng & déréng & déréng & not yet \\
\hline dulór & dhèrèk & dhèrèk & relatives, folks \\
\hline enggon & nggén & enggèn & place \\
\hline gak & mboten & mboten & not \\
\hline eró & sumerap & sumerep & to know, to recognize \\
\hline gelem & purun & purun & to want \\
\hline góróng & déréng & déréng & not yet \\
\hline isok & saget & saged & can, to be able \\
\hline isók & injing ngènjing & énjing & morning \\
\hline jeneng & nami & nami & name \\
\hline kabèh & sedoyo & sedaya & all \\
\hline kéné & ngriki & ngriki & here \\
\hline kerjo & damel & damel & work \\
\hline kondho & sanjang & sanjang, criyos & to say, to tell \\
\hline (k)apé(né), (k)até & badhé & badhé & FUT \\
\hline keno & kènging† & kénging & to be affected by \\
\hline kon & sampèan & sampéyan & you \\
\hline kongkon & kèngkèn ${ }^{\dagger}$ & kèngkèn & to order sb. to do \\
\hline kónó & ngriku & ngriku & there \\
\hline kudu & kedaht & kedah & must \\
\hline limo & gangsal & gangsal & five \\
\hline loro & sakit & sakit & sick, ill \\
\hline lóró & kaléh & kalih & two \\
\hline ma(e)ng & wau & wau & earlier this day \\
\hline manèh & maléh & malih & again \\
\hline mangan & nedho & nedha & to eat \\
\hline matèk & pejaht $^{\dagger}$ & pejah & dead, to die \\
\hline mau & wau & wau & earlier this day \\
\hline mèk & namung & namung & only \\
\hline metu & medal & medal & to come out \\
\hline mlaku & $\operatorname{mlampah}^{\dagger}$ & mlampah & to walk \\
\hline móléh & mantók & mantuk & to return home \\
\hline mréné & mriki & mriki & to come here \\
\hline mrono ${ }^{\dagger}$ & mriko $^{\dagger}$ & mrika & to go yonder \\
\hline mrónó & mriku & mriku & to go there \\
\hline mulo & pramilo ${ }^{\dagger}$ & (pra)milo & therefore \\
\hline munggah ${ }^{\dagger}$ & menggah $^{\dagger}$ & menggah & as for, in connection with \\
\hline ndelok & ningali & ningal(i) & to see, to look at \\
\hline ndi & pundi & pundi & which \\
\hline ngekèk'i & sukani† & nyukani & to give \\
\hline ngarep & ngajeng† & ngajeng & next \\
\hline nggawé & ndamel & ndamel & to make, to wear \\
\hline nggowo & mbeto & mbekta & to bring, to carry \\
\hline
\end{tabular}




\begin{tabular}{|c|c|c|c|}
\hline ngisor & ngandhap $^{\dagger}$ & ngandhap & below, under, lower \\
\hline ngkók & mangkét & mangké & later \\
\hline olèh & angsal & angsal & to get, to obtain \\
\hline onok & wonten & wonten & there is \\
\hline papat & sekawan & sekawan & four \\
\hline perkoro & perkawis ${ }^{\dagger}$ & perkawis & case \\
\hline piro & pinten & pinten & how much, how many \\
\hline rego & regi ${ }^{\dagger}$ & regi & price \\
\hline rolas & kaléh welas & kalih welas & twelve \\
\hline rolikór & kaléh likór & kalih likur & twenty-two \\
\hline rong puló & kaléh doso & kalih dasa & twenty \\
\hline sedulór & sedhèrèk & sadhèrèk & sibling \\
\hline sék & rumiyén & rumiyin & first \\
\hline sék & tasék & taksih & still \\
\hline séng & ingkang & ingkang & REL \\
\hline separó & sepaléh† & sepalih & a half \\
\hline sepuló & sedoso & sedasa & ten \\
\hline sésók & mbènjing ${ }^{\dagger}$ & bénjing & tomorrow, in the future \\
\hline suelas & setunggal welas & setunggal welas & eleven \\
\hline siji/sithok & setunggal & setunggal & one \\
\hline soko & sa(ng)king, seking ${ }^{\dagger}$ & saking & from \\
\hline sopo & sinten & sinten & who \\
\hline tau & naté ${ }^{\dagger}$ & naté & ever \\
\hline telu & tigo & tiga & three \\
\hline temenan & sa'èstu† & (sa)èstu & really \\
\hline turu & tilem & tilem & to sleep \\
\hline teko(k) & sa(ng)king, sekingt, dhateng ${ }^{\dagger}$ & saking, dhateng & from \\
\hline wedi & ajréh†, wedos ${ }^{\dagger}$ & ajrih & to be afraid \\
\hline wedhus & mèndo ${ }^{\dagger}$ & ménda & goat \\
\hline wong & tiang & tiyang & person \\
\hline yo'opo & kados pundi ${ }^{\dagger}$ & kados pundi & how \\
\hline
\end{tabular}

As there are only about 400 krama inggil (honorific) words and not more than $15 \mathrm{krama}$ andhap (deferential) expressions in $\mathrm{St} \mathrm{J}$, it is expected that their number is very small in $\mathrm{SuJ}$. I have come across $16 \mathrm{kromo} \mathrm{inggil} \mathrm{(four} \mathrm{of} \mathrm{them} \mathrm{not} \mathrm{intelligible} \mathrm{to} \mathrm{younger} \mathrm{speak-}$ ers) and only 11 kromo andhap terms (five of them not understood by younger speakers).

Table 4: Honorific words used in Surabayan Javanese

\begin{tabular}{llll}
\hline $\begin{array}{l}\text { SuJ low level } \\
\text { (ngókó) }\end{array}$ & $\begin{array}{l}\text { SuJ honorific } \\
\text { (kromo inggil) }\end{array}$ & $\begin{array}{l}\text { StJ honorific } \\
\text { (krama inggil) }\end{array}$ & $\begin{array}{l}\text { translation } \\
\text { (English) }\end{array}$ \\
\hline anak & $\begin{array}{l}\text { yugo } \text { yógo }{ }^{\dagger} \\
\text { prèso } \text { pèrso' }\end{array}$ & $\begin{array}{l}\text { putra } \\
\text { pirsa }\end{array}$ & $\begin{array}{l}\text { child, offspring } \\
\text { to know, to recognize }\end{array}$ \\
kondho & ngendiko & ngendika & to say \\
loro & gerah & gerah & sick, ill \\
lunggó & lenggah & lenggah & to sit \\
mangan & dhahar & dhahar & to eat \\
matèk & kapundhut', sèdo & kapundhut, séda & dead, to die \\
mlaku & tindak & tindak & to walk \\
mólèh & kondór & kondur & to return home \\
ndelok & mirsani & pirsa, mirsani & to see \\
ngekèk'i & maringaken & maringaken & to give \\
slamet & sugeng & sugeng & safe \\
teko(k) & rawóh & rawuh & to come \\
tuku & mundhut & mundhut & to buy \\
turu & saré & saré & to sleep
\end{tabular}

Some of the SuJ krama inggil terms above are only used in very special occasions, for example poro rawóh "people who have come (that is audience)". My SuJ informant told 
me that sugeng "safe" would probably be understood as a personal name by younger residents of Surabaya.

Table 5: Deferential vocabulary in Surabayan Javanese

\begin{tabular}{|c|c|c|c|}
\hline $\begin{array}{l}\text { SuJ low level } \\
\text { (ngókó) }\end{array}$ & $\begin{array}{l}\text { SuJ deferential } \\
\text { (kromo andhap) }\end{array}$ & $\begin{array}{l}\text { StJ deferential } \\
\text { (krama andhap) }\end{array}$ & $\begin{array}{l}\text { translation } \\
\text { (English) }\end{array}$ \\
\hline aku & dalem ${ }^{\dagger}$ & dalem & $\mathrm{I}, \mathrm{me}$ \\
\hline dikandhani & didhawóhi† & di(pun)dhawuhi & to be told by sb. \\
\hline kondho & matór & matur & to say \\
\hline mbóh mbuh & duko & duka & to not know \\
\hline ngekèk'i & ngaturi† & ngaturi & to give \\
\hline ngongkon & ngaturi & ngaturi & to ask sb. to \\
\hline njalók & nyuwunt & nyuwun & to ask for \\
\hline pèngen eró & nyuwun prikso ${ }^{\dagger}$ & nyuwun priksa & to want to know \\
\hline sapurané & nyuwun sèwu & nyuwun sèwu & to apologize \\
\hline mampir & sowan & sowan & to visit, to pass by \\
\hline suwun & matór nuwun & matur nuwun & to thank \\
\hline
\end{tabular}

Out of the 11 kromo andhap expressions above, only matór nuwun "thank you" and nyuwun sèwu "excuse me" are regularly used. Younger speakers of SuJ usually only know the words in their passive form from their parents, for example diaturi "to be told (by sb. superior)".

From the little amount of the correspondences between $\mathrm{SuJ}$ and $\mathrm{StJ}$ high level words with a ration of 1612 to 84 (5\%) for krama and 446 to 16 (4\%) for krama inggil, it becomes obvious that speakers of $\mathrm{SuJ}$ fear to use their dialect in areas where speech levels are an essential part of the language. The avoidance of SuJ outside of East Java is encouraged by Indonesian Malay, which serves as a perfect substitute for Javanese due to the absence of a speech level system.

\section{POLITE VOCABULARY CORRESPONDING TO STANDARD JAVANESE MADYA}

Of the few high level words that are regularly used in $\mathrm{SuJ}$ most of them correspond to madya in StJ, the mid level with not more than 61 lemmata. There is no mid level in SuJ. For example, jaréné "he/she says" can be made more polite, especially when referring to God or highly esteemed persons, by using terosé, which is the mid level in StJ. The high level lexeme of StJ is criyosipun, which is never heard of in SuJ although it is understood by the older generation. The following table lists all $\mathrm{SuJ}$ high level words I have come across so far with their correspondences to the StJ mid level. Many of them had already been observed by Hoogervorst (2008:33). Words indicated by a cross ( $\left.{ }^{\dagger}\right)$ are very seldom used by or unintelligible to younger speakers. This list may not be complete yet, but as the StJ mid level vocabulary is very limited, not many more terms are expected to be added here. The ration of $61 \mathrm{StJ}$ madya words to 29 of them $(48 \%)$ used in $\mathrm{SuJ}$ shows that the mid level vocabulary is generally better accessible to $\mathrm{SuJ}$ speakers. The words marked with a cross $\left(^{\dagger}\right)$ are not understood by the younger generation. 
Table 6: Correlation between SuJ high level and StJ mid level vocabulary

\begin{tabular}{|c|c|c|c|c|}
\hline $\begin{array}{l}\text { SuJ low level } \\
\text { (ngókó) }\end{array}$ & $\begin{array}{l}\text { SuJ high level } \\
\text { (alus) }\end{array}$ & $\begin{array}{l}\text { StJ mid level } \\
(\text { madya) }\end{array}$ & $\begin{array}{l}\text { StJ high level } \\
\text { (kromo) }\end{array}$ & $\begin{array}{l}\text { translation } \\
\text { (English) }\end{array}$ \\
\hline aé & mawon & mawon & kémawon & just \\
\hline ambèk, mbarèk & kaléh & kalih & kaliyan & and, with \\
\hline bójó & setri† & setri & sémah & wife \\
\hline iki & niki, meniki† & niki & menika, punika ${ }^{\dagger}$ & this \\
\hline $\mathrm{iko}^{\dagger}$ & niko', meniko ${ }^{\dagger}$ & nika & menika, punika ${ }^{\dagger}$ & yonder \\
\hline $\mathrm{iku}$ & niku, meniku $^{\dagger}$ & niku & menika, punikat & that \\
\hline jaréné & terosé & trosé, trosipun & criyosipun & he/she said \\
\hline nang & teng & teng & dhateng & to \\
\hline nang, nok, ndhék & teng & teng & wonten (ing) & in, at \\
\hline ngéné & ngèten, ngéten ${ }^{\dagger}$ & ngèten & ngaten & like this \\
\hline ngkók & mengké & mengké & mangké & later \\
\hline ngónó & ngóten & ngoten & ngaten & like that there \\
\hline ngono ${ }^{\dagger}$ & ngaten ${ }^{\dagger}$ & ngaten & ngaten & like that \\
\hline olèh & kantók & kantuk & pikantuk, angsal & to get \\
\hline onok & ènten & ènten & wonten & there is/are \\
\hline opo & nopo & napa & menapa, punapat & what? \\
\hline sak'iki & sakniki & saniki & sakmenika, sapunika ${ }^{\dagger}$ & now \\
\hline sakméné & sakmènten ${ }^{\dagger}$ & semènten & samanten & this much \\
\hline sakmono & sakmanten ${ }^{\dagger}$ & semanten & samanten & that much \\
\hline sakmónó & sakmonten $^{\dagger}$ & semonten & samanten & that much there \\
\hline sék & kriyén† & kriyin & rumiyin & first \\
\hline sék & meséh, teséh & mesih, tesih & taksih & still \\
\hline takok & tanglet ${ }^{\dagger}$ & tangled & takèn & to ask \\
\hline tutug, teko(k) & dugi & dugi & dumugi & to arrive \\
\hline wés & (m)pun & (m)pun & sampun & already \\
\hline wésan & mpunan & mpunan & sampunan & $\mathrm{DM}$ \\
\hline & nggéh & nggih & inggih & yes, also, DM \\
\hline yo'opo & (ke)pripun & (ke)pripun & kados pundi & how? \\
\hline
\end{tabular}

\section{POLITE VOCABULARY CORRESPONDING TO STANDARD JAVANESE NGOKO}

In very rare cases, $\mathrm{SuJ}$ polite vocabulary has been taken from StJ ngoko. In none of these cases, they should be called alus because there is usually another high level equivalent in SuJ, for example matèk "dead", more polite mati (from the StJ low level or from Indonesian Malay), honorific sèdo. It is generally accepted to say kulo mboten ajeng mati "I don't want to die", but rather improper to say emak kulo mpun mati "my mother has died". For the latter, most SuJ speakers would use sèdo, while for the former even matèk would be fine. Polite words of this category are mainly used when younger speakers talk to or about an older, respected person and either do not know the correct high level counterpart or feel that it would sound too stilted. An example I got from $4.2 \%$ of the respondents in my survey was the sentence bapakku ora iso nukokno aku sepeda motor "my father cannot buy me a motorcycle", in which ora "not" and iso "can" are both taken from StJ low level, while nukokno "to buy for" is dialectal SuJ low level. The entire sentence shows no high level morpheme but sounds more polite than bapakku gak isok nukokno aku sepeda motor (answered by 9.1\%) because it has the StJ forms ora and isa (pronounced [' $P$ i.so] and therefore colloquially written iso) instead of dialectal gak and isok, respectively. The following list shows some of those occurrences compared to StJ low level. 
Table 7: Correspondence of SuJ polite words to StJ low level vocabulary

\begin{tabular}{|c|c|c|c|c|c|}
\hline $\begin{array}{l}\text { SuJ low level } \\
\text { (ngókó) }\end{array}$ & $\begin{array}{l}\text { SuJ polite } \\
\text { (luéh alus) }\end{array}$ & $\begin{array}{l}\text { SuJ high level } \\
\text { (alus) }\end{array}$ & $\begin{array}{l}\text { StJ low level } \\
\text { (ngoko) }\end{array}$ & $\begin{array}{l}\text { StJ high level } \\
\text { (kromo) }\end{array}$ & $\begin{array}{l}\text { translation } \\
\text { (English) }\end{array}$ \\
\hline aé & waé & mawon & waé, baé & kémawon & just \\
\hline ambèk, mbarèk & karó & kaléh & karo & kaliyan & and, with \\
\hline & ora & mboten & ora & mboten & not \\
\hline isok & iso & saget & (b)isa & saged & can \\
\hline matèk & mati & sèdo & mati & pejah & dead, to die \\
\hline móléh & mulih & $\begin{array}{l}\text { wangsul, kondór, } \\
\text { mantók }\end{array}$ & mulih & mantuk & to return home \\
\hline moto & mripat & - & mata, mripat & paningal & eye \\
\hline ndelok & ndeleng & sumerap, mirsani & ndeleng & ningal & to see \\
\hline ngkók & mengkó & (e)ngken, ken & mengko & mangké & later \\
\hline -no & -aké & -aken & -aké & aken & $\begin{array}{l}\text { applicative suf- } \\
\text { fix }\end{array}$ \\
\hline takok & takon & tanglet $^{\dagger}$ & takon & takèn & to ask \\
\hline yo' оро & piyé & $\begin{array}{l}\text { yoknopo, yak- } \\
\text { nopo, pripun, } \\
\text { kepriyé }\end{array}$ & piyé, pripun & kados pundi & how? \\
\hline
\end{tabular}

In a similar way, expressions can be made more polite in $\mathrm{SuJ}$ by adding polite affixes to low level roots, for example ngirimaken "to send" (instead of StJ ngintunaken), kulo crita'aken "to be told about by me" (instead of StJ kula cariyosaken), jarénipun "he/she says" (instead of StJ criyosipun) or by using high level roots with low level affixes, for example numbasno "to buy for" or numbas(a)ké "id." (instead of StJ numbasaken), ngendikané "he/she says" (instead of StJ ngendikanipun).

A special case is the low level SuJ word lué "hungry" corresponding to low level CJ ngelih "hungry" and WJ kencot (Nothofer 1981: Maps 274, 275 \& 276), whereas in CJ lué is regarded slightly more polite than ngelih.

\section{USING ANOTHER LEMMA AS POLITE VOCABULARY}

In $\mathrm{SuJ}$, a discourse is often made more polite or very refined by employing a high level equivalent of another lemma, a literary word with no indication of politeness, or a loan from Indonesian Malay. A few of the respondents in my survey, especially younger ones, simply gave the Indonesian Malay translation when asked for the polite correspondence of a word, for example menanyakan (2,4\%) for takok "to ask", memandang $(2,4 \%)$ for ndelok "to see", wafat ${ }^{29}(1,8 \%)$ for matèk "dead, to die", mendapatkan $(2,4 \%)$ for olèh "to get", and katanya for jaréné "he/she says" (1,2\%). Some of my observances for this category are listed in the table below.

Table 8: Alternative/Non-standard SuJ high level equivalents

\begin{tabular}{lllll}
\hline $\begin{array}{l}\text { SuJ low level } \\
(n g o ́ k o ́)\end{array}$ & $\begin{array}{l}\text { SuJ high level } \\
(\text { alus })\end{array}$ & $\begin{array}{l}\text { Alternative high level } \\
(\text { alus })\end{array}$ & $\begin{array}{l}\text { StJ high level } \\
(\text { krama })\end{array}$ & $\begin{array}{l}\text { translation } \\
\text { (English) }\end{array}$ \\
\hline jaréné & terosé & $\begin{array}{l}\text { ngendikanétt, sanjangé, kan- } \\
\text { dhané } \\
\text { sakit, sa(h)é, anglah } \\
\text { wafat, tilar }\end{array}$ & criyosipun & he/she says \\
$\begin{array}{l}\text { loro } \\
\text { matèk }\end{array}$ & $\begin{array}{l}\text { gerahtt } \\
\text { sèdott }\end{array}$ & $\begin{array}{l}\text { sakit, gerahtt } \\
\text { pejah, sédatt }\end{array}$ & $\begin{array}{l}\text { sick, ill } \\
\text { dead, to die }\end{array}$
\end{tabular}

29 The word wafat is originally from Ar. وفاة wafä(tun) and is considered literary in Javanese. In Indonesian, it is usually used for very respected persons, kings, the sultan, and religious leaders or prophets. 
móléh

ndelok

olèh wangsul

sumerap

angsal mantók, kondórt†

mirsani ${ }^{\dagger \dagger}$, nyawang, mriksani ${ }^{\dagger \dagger}$

éntók, keparingantt mantuk, kondurtt

ningal, mirsani ${ }^{\dagger}$

angsal to return home

to see

to get, obtain

The chart above needs some explanation. Words marked with a double cross $\left({ }^{\dagger \dagger}\right)$ are in fact honorifics but are given here for comparison. Generally, the high level of jaréné "he/ she says" in SuJ is terosé, but in my survey 7.3\% claimed ngendikané/ngendikanipun, $2.4 \%$ claimed sanjangé/sanjangipun, and another $1.2 \%$ claimed kandhané to be the high level equivalent. It is noteworthy that in StJ ngendika is the honorific form of kandha "to say, to talk, to speak" (SuJ: kondho) and sanjang is the high level of tutur "to advice, to say".

The case of loro "sick" is a little mysterious. In my survey, $47.3 \%$ (the absolute majority) gave gerah as the high level form while it is in fact the honorific. The StJ high level correspondence sakit was only given by 3.6\%. Even more respondents, that is $4.8 \%$, gave $s a(h) e ́$ and one person answered saré for the high level of loro. For the time being, I cannot explain these forms, but they seem to be either a corruption of sakit > *sakét > ${ }^{*} s a^{\prime} e t>s a(h) e ́$ (though highly doubtful as these sound changes are not regular) or taken from saré, the honorific of turu "to sleep" with the meaning "to lie down (because of illness)". Hoogervorst (2008:32) has found yet another high level form, that is anglah, but none of my SuJ informants could confirm this, although it is listed in Poerwadarminta et al. (1939:16) as high level of some dialect.

When my respondents were asked to give the high level equivalent of ndelok "to see", about $24.8 \%$ answered ningali/tingal/tingali/ketingal, 19.1\% answered sumerap/sumerep, another $11.8 \%$ answered mirsani/mrésani/mersani, $3 \%$ gave nywang, and $1.8 \%$ gave mriksani. These discrepancies result from the confusion of the three lemmata ndelok "to see, to look at" (StJ: ndeleng), eró "to know, to recognize" (StJ: weruh), ngerti "to know, to understand" (StJ: ngerti). Their StJ high level equivalents are ningal, sumerep, and ngertos, but the common honorific of weruh and ngerti is pirsa/mirsani with the alternative priksa/mriksani, whereas ndeleng has no honorific. This leads to confusion among SuJ speakers, who are not very familiar with the speech level system, thus the common high level form is sumerap with mirsani being the honorific for all of the three lemmata. The SuJ alternative nyawang (root form sawang) "to gaze at" is a lemma on its own.

A similar case is olèh "to obtain": In my survey, $23.9 \%$ answered angsal when asked about the high level form of olèh "to give"; 3.6\% answered éntók. However, éntók is another lemma in StJ meaning "to obtain (permission or a spouse)" with pikantuk being its high level correspondence.

Hoogervorst (2008:32) classifies boyo "crocodile", glathi "knife", ngarepan "in front of", pelem "manggo", and pasér "sand" as high level for bajul, lading, ngadhepan, poh, and wedhi, respectively, however I could not come to an agreement on these with my informants and would consider all of them synonyms of their so-called low level forms. According to my own study on these words, boyo, lading, ngarepan, poh, and pasir are the most commonly used terms with no indication of politeness. Some of my SuJ informants told me that only boyo is used in $\mathrm{SuJ}$ and that bajul ${ }^{30}$ sounds "too Central

30 The local football team Persebaya is nicknamed Bajul Ijo "green crocodile", but my SuJ informants told me that bajul here may refer to the CJ way of calling the Surabaya team. 
Javanese", an informant from Malang admitted that boyo is indeed slightly more polite than bajul, and another informant from Surabaya said that bajul would be more polite than boyo. All my informants rejected the word ngadhepan and preferred ngarepan. The difference between poh "ripe mango" and pelem "mango fruit" lies in their usage. It is possible to say wit pelem "mango tree", but not *wit poh "tree of ripe mangos". Lading "knife" is the common word for any kind of knife as a utensil, especially a kitchen knife, whereas glathi "combat knife" is rarely used and refers to a weapon.

\section{INNOVATIONS OF POLITE VOCABULARY}

A salient feature of $\mathrm{SuJ}$ politeness is that some words have a high level allolex not or rarely found in other dialects of Javanese. Some of them have already been identified others by Kisyani-Laksono (2004a:196-203), others by Hoogervorst (2008:32-34), and I have come across some more, most of them found in the table below. These innovations are often called boso dèso or kromo dèso "village language of courtesy". However, further research is needed to compile a complete list of all idiosyncratic high level lexemes found in SuJ. The cross $\left(^{\dagger}\right)$ indicates words that are not understood by most younger speakers in Surabaya.

Table 9: Surabayan Javanese innovations of high level vocabulary

\begin{tabular}{|c|c|c|c|}
\hline $\begin{array}{l}\text { SuJ low level } \\
\text { (ngókó) }\end{array}$ & $\begin{array}{l}\text { SuJ high level } \\
\text { (alus Suroboyo) }\end{array}$ & $\begin{array}{l}\text { StJ high level } \\
(\text { krama) }\end{array}$ & $\begin{array}{l}\text { translation } \\
\text { (English) }\end{array}$ \\
\hline ali-ali & lèpèn†31 & sesupé & finger ring \\
\hline ayók & ndaweg ${ }^{\dagger}$ & sumangga & as you wish \\
\hline duduk & dédékt & sanès & nominal negation \\
\hline eró & prèso $^{\dagger}$ (< pèrso) & sumerep & know \\
\hline gudhang & gidhang ${ }^{\dagger}$ & - & storeroom \\
\hline iki & meniki & menika & this \\
\hline jancók & hancik, jangkrik ${ }^{32}$ & - & fuck, damn \\
\hline jaréné & picawisipunt & criyosipun & he/she says \\
\hline kabèh & sedanten ${ }^{\dagger}$ & sedaya & all \\
\hline kon & peno & sampéyan & you \\
\hline kulino & kulinten ${ }^{\dagger}$ & - & to be acquainted with \\
\hline kunéng & jeni† & jené & yellow \\
\hline lali & $\operatorname{lipco}^{\dagger}$ & kesupèn & to forget \\
\hline legi & manis & -33 & sweet \\
\hline liwat & lintang ${ }^{\dagger}$ & langkung & to go past \\
\hline loro & sa(h)é ${ }^{\dagger}$ & sakit & ill, sick \\
\hline mólai & mèlai ${ }^{\dagger}$ & milai & to begin \\
\hline njalano & njalanaken & nglampahaken & to put in motion \\
\hline ndèlèh & tilah† & - & to put, to place \\
\hline ndelok & meningo $^{\dagger}$ & ningali & to see \\
\hline ngguyon & ndhagelt & - & to joke \\
\hline nginang & mucang ${ }^{\dagger}$ & nggantèn & to chew betel \\
\hline nginep & ndalu $^{\dagger}$ & nyipeng & to stay overnight \\
\hline ngkók & (e)ngken, ken, ngkin, (ma)ngkin & mangké & later \\
\hline njlèntrèkno & njelasaken & njlèntrèhaken & to explain \\
\hline olèh & nyagedaken ${ }^{\dagger}$ & angsal & to obtain \\
\hline opóo & nopo' ${ }^{\dagger}$ & - & why \\
\hline
\end{tabular}

31 None of my informants recognized this word, but apparently Hoogervorst came across it and it is also listed in Nothofer (1981: Map 47) for the WJ of Tegal and Pemaling.

32 Some people say that hancik and jangkrik are less impolite while others say that they are more polite than jancók.

33 StJ has no high level word for legi "sweet", but Nothofer (1981: Map 259) has reported the legi/manis (from Indonesian Malay) difference for other dialects in Central Java, too. 


$\begin{array}{llll}\text { pisan } & \text { pindhah }^{\dagger} & - & \text { first, at the same time } \\ \text { sak'iki } & \text { sakmeniki }^{\dagger} & \text { samenika } & \text { now } \\ \text { suloyo } & \text { sulanten } & - & \text { to quarrel } \\ \text { tentang } & \text { bap } & - & \text { about } \\ \text { trimo } & \text { trami } & \text { trimah } & \text { to accept } \\ \text { tukang } & \text { tikang }^{\dagger} & - & \text { workman } \\ \text { yo'opo } & \text { yoknopo, yaknopo } & \text { kados pundi } & \text { how }\end{array}$

Some more high level words in this category are listed by Hoogervorst (2008:32), which rather seem like occasionalisms, idiosyncratic to certain families, or humorous, for example place names like Sidajeng (Sidayu), Mambeng (Malang), Tandhes (Gresik), Suropringgo (Suroboyo), Tiban (Tuban), and Pasedhahan (Pasuruan) ${ }^{34}$. Of these, only Tiban has been accepted by one of my informants, the rest have been derided. None of the so-called polite city names are considered true high level forms among younger $\mathrm{SuJ}$ speakers. For further explanations regarding these place names, see Krauße (2017:80).

\section{AWARENESS OF POLITENESS IN SURABAYAN JAVANESE}

Generally, most speakers of Javanese consider SuJ to be extremely rude and in no case refined with regard to speech levels and politeness. When I asked about words of higher speech levels for my research in Surabaya, the people often gazed at me asking in Indonesian Malay Emang di Surabaya ada kromo ta? [So, there's really a high level in Surabaya?], while offering me some explanation that only Yogyakarta and Solo use those speech levels that are derived from kawi (Old Javanese) and that Surabayans never use them. Indeed, in my SuJ corpus, only 417 out of 13,298 tokens (3.1\%) can be considered high level, honorific, or deferential vocabulary, and in almost all instances these are used by old people.

Furthermore, people in Surabaya who want to speak the refined way, sometimes confuse the high level (kromo) with honorifics (kromo inggil), so that kulo dhahar "I eat ${ }_{\mathrm{HON}}$ " might be used instead of kulo nèdho "I eat", dhéé mantók "he/she goes home" instead of dhéé kondór "he goes home ${ }_{\text {HоN" }}$ etcetera. Although these sentences are regarded as odd by some SuJ speakers, others are not bothered to hear them. In Central Java, it is considered very uneducated to use honorifics for oneself and non-honorifics for other persons whenever an honorific word exists. However, phrases such as sinten naminé? "what's your name?" (StJ: sinten asmanipun?) and asto kulo "my hand" (StJ: tangan kula) are common in $\mathrm{SuJ}$.

My survey of 165 respondents shows how difficult it is for SuJ speakers to find the corresponding high level equivalent. When asked for the high level of mangan "to eat", $83 \%$ answered dhahar, which is the honorific; only $10.6 \%$ answered nèdho, the high level in StJ. The same distribution could be observed with loro "sick" (honorific: gerah 48.5\%;

34 Pasedhahan is mentioned several times Babad Kraton, for example in Cantos XXI.58, XXXIV.65, XLII.4-5, and LXIII 86 (Sunjata, Supriyanto, and Ras 1992). The Javanese court chronicle is mostly written in krama. Oetomo (1987:13) cites the Encyclopædie van Nederlandsch-Indië (Stibbe 1919:358) that Pasedhahan is the high level equivalent of the designation for the city of Pasuruan, which had apparently already gone out of use at the time of Oetomo's research. The formation is analogical to high level sedhah "betel leaves" from low level suruh. 
high level: sakit 3.6\%; Surabayan high level: sa(h)é 5.4\%) and matèk "dead, to die" (honorific: sèdo 65.8\%; high level: pejah 3.3\%), but not with turu "to sleep" (honorific: saré $40 \%$; high level: tilem $53.9 \%$ ). This is a strong indicator for the unawareness of a refined politeness system among Surabayans.

The only SuJ high level expression used in slang is ngèten pun "just like this", always said in combination with a thumbs-up gesture. Yet, people who make use of this expression do not communicate politeness. The only Javanese high level word that has made its way into colloquial Indonesian Malay is saking "from", the low level equivalent being soko/teko $(k)$. However, the meaning has shifted to "due to" and the construction is always saking + adjective $+-n y a$, which is different from Javanese, though.

Coming back to the question whether or not there's a high level in Surabaya, the answer is 'yes', but it needs to be added that recently it has lost too much of the once already-rudimentary speech level system to be classified as such, especially among younger speakers. The most common high level words are only these: sampèan "you", kulo "I", niki "this", niku "that", and mboten "not", in descending order according to their occurrence. A sentence can easily be made polite in SuJ by changing iki and iku to niki and niku, which even have the same number of syllables, as opposed to most other words of the high level register (Kisyani-Laksono 2004a:200-204). The other common high level words are the negative particle mboten and the pronouns of the 1SG and the 2SG, suggesting a classification of $\mathrm{SuJ}$ as a multi-pronominal register system like Thai or Sinhalese, but since kulo and mboten are much rarer than sampèan, I advocate a classification as a dialect with a binary distinction in pronouns, similar to the T-V distinction in many languages of Europe. As already discussed above, speakers of languages with a T-V distinction are by no means impolite but the system is simply different. In the same way, speakers of SuJ are not impolite but their politeness system is different from that of CJ. This is especially true for the Javanese used among younger speakers in Surabaya.

\section{CONCLUSION}

Although Javanese has been well studied throughout the past century, still too little is known about its highly diverse dialects. This paper has been an attempt to summarize the most prominent features of Surabaya's politeness. The fact that it differs much from StJ is not new, but I have attempted to predict what the future of SuJ would look like: Whereas CJ is very conservative in the extensive use of its speech level system, being even more refined than Japanese and Korean, the Javanese of Surabaya on the contrary is very limited in the use of speech levels. Even though bearing in mind that $\mathrm{SuJ}$ had never developed a speech level system as is found in CJ due to the city's distance to Yogyakarta and Surakarta, it is noteworthy that the rare findings of high level vocabulary among young speakers in Surabaya indicate that $\mathrm{SuJ}$ is gradually giving way to a binary $\mathrm{T}-\mathrm{V}$ distinction, which is similar to colloquial Indonesian Malay and many languages of Europe. This development is best seen in younger speakers who merely use the polite sampèan and non-polite kon or kinship terms to express politeness, some dynamic verbs such as "to eat", "to sleep" or "to die", and only sporadically throwing in some mid level adverbs to make their conversation more polite. This roughly corresponds to what we find in German, a typical T-V language: the plain 2sG is $d u$, the 
polite 2SG is Sie, the verbs "to eat" and "to die" are generally translated as essen and sterben, respectively, but they also have polite equivalents such as speisen "to dine" and versterben "to pass away". German also has traces of royal language, for example Ihr for the 2SG, dinieren "to sup", and verscheiden "to decease", comparable to the few traces of honorifics in SuJ that are hardly ever employed in everyday conversation. The parallels in politeness between German and SuJ are striking and suggest that $\mathrm{SuJ}$ is on the way to develop a mere $\mathrm{T}-\mathrm{V}$ distinction for politeness with $k$ on for $\mathrm{T}$ and sampèan for $\mathrm{V}$.

Older speakers still use many words of higher registers, however inconsistently mixing StJ madya, krama, or krama inggil vocabulary for the polite language. The case of Surabaya is different from Tenggerese which had never developed any speech level system and only recently absorbed some krama loanwords from Standard Javanese through education. My survey analysis has shown that most speakers of SuJ are not always certain what the high level equivalent of a given lemma actually is. This is a clear indicator for the decline of the speech levels among older speakers. Nearly all occurrences with high level expressions in my corpus are in context with older speakers, especially in adult comedy shows or interviews with persons older than 50 . One main difference between European T-V languages like German and $\mathrm{SuJ}$ among younger speakers is that children address their parents with $d u(T)$ in German nowadays but with kinship terms in SuJ. The use of kinship terms in European T-V languages was common practice is the past, though (Clyne, Norrby, and Warren 2009:86).

Despite the pride for their dialect and its constant use in Surabaya and around, many Surabayans fear speaking their mother tongue in areas where the classical speech level system is still prominent and switch to Indonesian Malay, which has no speech levels.

\section{REFERENCES}

Adelaar, K. A. 1989. "Review: Studies in Austronesian Linguistics by Richard McGinn." Journal of Southeast Asian Studies 20(2):316-319.

https:/ / www.jstor.org/stable/20071094

Adelaar, K. A. 2005a. “The Austronesian languages of Asia and Madagascar: a historical perspective." Pp. 1-42 in The Austronesian Languages of Asia and Madagascar, edited by K. Alexander Adelaar and Nikolaus Himmelmann. London; New York: Routledge.

Adelaar, K. A. 2005b. “Malayo-Sumbawan.” Oceanic Linguistics 44(2):357-388. https://muse.jhu.edu/article/191360/pdf

Adipitoyo, Sugeng, Bambang Yulianto, and Totong Tirtawijaya. 1999. Morfofonemik Bahasa Jawa dialek Surabaya. Jakarta: Pusat Pembinaan dan Pengembangan Bahasa, Departemen Pendidikan dan Kebudayaan.

Agha, Asif. 1993. "Grammatical and Indexical Convention in Honorific Discourse." Journal of Linguistic Anthropology 3(2):131-163. http:// onlinelibrary.wiley.com/doi/10.1525/jlin.1993.3.2.131/abstract

Ali, Hasan. 2002. Kamus Bahasa Daerah Using-Indonesia. Banyuwangi: Dewan Kesenian Blambangan. 
Anggraini, Bea. 2005. “Faktor-faktor penanda kesantunan tuturan imperatif dalam bahasa Jawa dialek Surabaya: Analisis pragmatik." Humaniora 17(1):67-77.

https://journal.ugm.ac.id/jurnal-humaniora/article/view/829/669

Badan Pusat Statistik. 2010. “Kota Surabaya.” Sensus Penduduk 2010.

https:/ / sp2010.bps.go.id/index.php/ site?id=3578000000\&wilayah=Kota-Surabaya

Barber, Josephine. 1985. German for Musicians: An essential handbook for musicians and music lovers. Bloomington: Indiana University Press.

Blust, Robert. 1981. “The reconstruction of proto-Malayo-Javanic: an appreciation." Bijdragen tot de Taal-, Land-en Volkenkunde 137(4):456-469.

http://www.jstor.org/stable/27863392

Blust, Robert. 2010. “The Greater North Borneo Hypothesis.” Oceanic Linguistics 49(1):44-118.

Blust, Robert. 2013. The Austronesian Languages: Revised Edition. Canberra: Pacific Linguistics, Australian National University.

Brown, R. and A. Gilman 1960. "The Pronouns of Power and Solidarity.” Pp. 253-276 in Style in Language, edited by T. A. Sebeok. Cambridge: M.I.T. Press.

http://www.ehu.eus/seg/_media/gizt/5/5/brown-gilman-pronouns.pdf

Brown, Penelope and Stephen Levinson 1978. “Universals in language usage:

Politeness phenomena." Pp. 56-289 in Questions and politeness: Strategies in social interaction. Cambridge: Cambridge University Press.

Bühler, Karl. 1934. Sprachtheorie: die Darstellungsfunktion der Sprache. Jena: Gustav Fischer Verlag.

Clyne, Michael, Catrin Norrby, and Jane Warren. 2009. Language and Human Relations: Styles of Address in Contemporary Language. Cambridge: Cambridge University Press.

Clynes, Adrian 1994. “Old Javanese influence in Balinese: Balinese speech styles.” Pp. 141-180 in Language Contact and Change in the Austronesian World, edited by Tom Dutton and Darrell T. Tryon. Berlin; New York: Mouton de Gruyter.

Conners, Thomas J. 2008. Tengger Javanese. Dissertation. New Haven: Yale University.

Coulmas, Florian 1992. "Linguistic etiquette in Japanese society." Pp. 299-323 in

Politeness in Language: Studies in its History, Theory and Practice. Berlin; New York:

Mouton de Gruyter.

Dick, Howard H. 2002. Surabaya, City of Work: A Socioeconomic History, 1900-2000.

Athens, Ohio: Ohio University Press.

Djajengwasito, Subandi. 1975. Javanese Speech Styles: A Multiple Discriminant Analysis of Social Constraints. A Thesis. Ithaca: Cornell University.

Djupri, M., ed. 2008. Kamus Suroboyoan-Indonesia. Surabaya, Henk Publica.

Drakeley, Steven. 2005. The History of Indonesia. Westport: Greenwood Press. 
Emeneau, Murray B. 1980. Language and Linguistic Area: Essays by Murray B. Emeneau. Stanford: Stanford University Press.

Errington, J. J. 1982. “Speech in the royal presence: Javanese palace language." Indonesia 34:89-101. http:/ / cip.cornell.edu/seap.indo/1107017332

Errington, J. J. 1985. Language and Social Change in Java: Linguistic Reflexes of Modernization in a Traditional Royal Polity. Athens, Ohio: Ohia University Center for International Studies.

Errington, J. J. 1988. Structure and Style in Javanese: A Semiotic View of Linguistic Etiquette. Philadelphia: University of Pennsylvania Press.

Errington, J. J. 1998. Shifting Languages: Interaction and Identity in Javanese Indonesia. Cambridge: Cambridge University Press.

Espree-Conaway, Deandré A. 2013. "Bahasa walikan malangan and the building of indo-javanese urban spaces." in NUL - New Urban Languages Conference Proceedings. Milan.

Esser, S. J. 1938. “Talen = Langues = Sprachen = Languages.” Pp. 9-9b in Atlas van tropisch Nederland. Amsterdam: Koninklijk Nederlandsch Aardrijkskundig Genootschap.

Fox, James J. 2005. “Ritual Languages, Special Registers and Speech Decorum in Austronesian Languages." Pp. 87-109 in The Austronesian Languages of Asia and Madagascar, edited by Alexander Adelaar and Nikolaus P. Himmelmann. $1^{\text {st }}$ ed. London; New York: Routledge.

Fritz, Sonja 1993. “Wilhelm Geigers Beitrag zur Erforschung des Dhivehi, der Staatssprache der Malediven." Pp. 15-32 in Münchner Studien zur Sprachwissenschaft. J.H. Röll.

Fritz, Sonja 2005. “Der sprachliche Ausdruck von Sozialstrukturen in Südasien.” Pp. 113-125 in Indogermanica: Festschrift Gert Klingenschmitt, edited by Günter Schweige. Taimering: Schweiger VWT-Verlag. titus.uni-frankfurt.de/personal/sf/sf2005d.pdf

Grice, H. Paul 1975. “Logic and conversation.” Pp. 41-58 in Speech acts. New York: Academy Press. http://www.ucl.ac.uk/1s/studypacks/Grice-Logic.pdf

Grijns, C. D. 1996. "Van der Tuuk and the Study of Malay." Bijdragen tot de Taal-, Land-en Volkenkunde 152(3):353-381. http://www.sabrizain.org/malaya/library/vandertuuk.pdf

Hadi, Sumukti R. 1971. Javanese Morphology and Morphophonemics. Dissertation. Ithaca: Cornell University.

Harjawiyana, Haryana and Th. Supriya. 2001. Kamus unggah-ungguh basa Jawa. Yogyakarta: Penerbit Kanisius.

Hatley, Ron 1984. "Mapping Cultural Regions of Java." Pp. 1-32 in Other Javas Away from the Kraton, edited by Ron Hatley, Jim Schiller, Anton Lucas, and Barbara MartinSchiller. Clayton: Monash University. 
Helmbrecht, Johannes. 2013. "Politeness Distinctions in Pronouns." The World Atlas of Language Structures Online. Max Planck Institute for Evolutionary Anthropology (Leipzig). http://wals.info/chapter/45.

Hermanto, Zarida. 1996. Perubahan pemanfaatan tanah di Gerbangkertosusila: Identifikasi mengenai kebijakan tata ruang, profil perekonomian, dan lahan pertanian. Jakarta:

Puslitbang Ekonomi dan Pembangunan, Lembaga Ilmu Pengetahuan Indonesia.

Hirth, Friedrich and W. W. Rockhill. 1911. Chau Ju-Kua: His Work on the Chinese and Arab Trade in the twelfth and thirteenth Centuries, entitled Chu-fan-chï. St. Petersburg: Printing Office of the Imperial Academy of Sciences.

Hoogervorst, Tom G. 2006. “Percampuran Bahasa di Surabaya: Pengaruh Bahasa Indonesia Terhadap Bahasa Jawa Suroboyan." Pendeta: Jurnal Bahasa, Sastra dan Budaya 2:59-74.

Hoogervorst, Tom G. 2008. “Basa Jawa Surabayaan: Describing Surabaya's Linguistic Ecology." MPhil Thesis, Leiden: Leiden University.

Hoogervorst, Tom G. 2009. “Urban dynamics: An impression of Surabaya's sociolinguistic setting." Wacana 11(1):39-56.

http://wacana.ui.ac.id/index.php/wjhi/article/view/143

Hoogervorst, Tom G. 2014. "Youth culture and urban pride: The sociolinguistics of East Javanese slang." Wacana 15(1):104-131.

http:/ /journal.ui.ac.id/index.php/wacana/article/view/4110

Horne, Elinor C. 1974. Javanese-English Dictionary. New Haven; London: Yale University Press.

Irvine, Judith T. 1998. “Ideologies of Honorific Language.” Pp. 51-67 in Language Ideologies: Practice and Theory, edited by Bambi B. Schieffelin, Kathryn A. Woolard, and Paul V. Kroskrity. New York; Oxford: Oxford University Press.

http:/ /journals.linguisticsociety.org/elanguage/pragmatics/article/download/226 L226-514-1-PB.pdf

Jakobson, Roman 1960. “Linguistics and Poetics.” Pp. 350-377 in Style in Language, edited by T. Sebeok. Cambridge: M.I.T. Press.

Junita, Nancy. 2016. “Cak Ikin, Animator di Balik Kartun Populer 'CuloBoyo'." Kalimantan.Bisnis.com.

http:/ / kalimantan.bisnis.com/read/20161203/220/608663/cak-ikin-animator-dibalik-kartun-populer-culoboyo

Kartomihardjo, Soeseno. 1981. Ethnography of Communicative Codes in East Java. $1^{\text {st }}$ ed. Canberra: Pacific Linguistics.

Kats, J. 1929. Serat warna sari Djawi: Inggih poenika pepețikan saking serat Djawi. ${ }^{\text {nd }}$ ed. Batavia: Visser Weltevreden.

Khristarini Mariana. 2005. Sikap tokoh masyarakat Surabaya terhadap bahasa "Suroboyoan" dalam berita Pojok Kampung JTV Surabaya. Thesis, Surabaya: Universitas Kristen Petra. 
Kisyani-Laksono. 1995. Bahasa Jawa dialek Jawa Timur di Mojokerto: Kajian geografi dialek. Dissertation, Yogyakarta: Universitas Gajah Mada.

Kisyani-Laksono. 1998. “Isolek Bahasa Jawa di Keduwung, Tengger.” Linguistik Indonesia 16(1,2):32-43. http:/ / www.linguistikindonesia.org/images/files/IsolekBahasaJawadiKeduwungTengger.pdf

Kisyani-Laksono. 1999. “Isolek Bahasa Jawa di Ujung Pangkah, Gresik.” Prasasti 9(32):33-43.

Kisyani-Laksono. 2000. “Isolek Bahasa Jawa di Tuban dan Bojonegoro.” Linguistik 18(2):67-76.

Kisyani-Laksono. 2001. "Identifikasi dialek dan subdialek Bahasa Jawa di Jawa Timur bagian utara dan Blambangan." Kongres Bahasa Jawa III:173-197.

Kisyani-Laksono. 2004a. Bahasa Jawa di Jawa Timur Utara dan Blambangan: Kajian Dialektologis. Jakarta: Pusat Bahasa, Departemen Pendidikan Nasional.

Kisyani-Laksono. 2004b. “Identifikasi Kosa kata Krama dalam Bahasa Jawa Dialek Jawa Timur dan Dialek Osing." Linguistik Indonesia 22(1):37-64.

http://www.linguistik-indonesia.org/images/files/IdentifikasiKosakataKrama.pdf

Krauße, Daniel. 2017. “A Description of Surabayan Javanese with Special Reference to its Linguistic Etiquette." Unpublished Master's Thesis, Frankfurt: Goethe University of Frankfurt. https:// doi.org/10.13140/rg.2.2.27512.14086

Kreemer, J. 1885. "Veertien dagen in Pasoeroeansch Tengger." Mededeelingen van wege het Nederlandsche Zendelinggenootschap 29:337-384.

Kummer, Manfred 1992. “Politeness in Thai." Pp. 325-336 in Politeness in Language: Studies in its History, Theory and Practice. Berlin; New York: Mouton de Gruyter.

Lee, Nam-Seok. 1996. Deixis und Honorifica: Allgemeine deiktische Phänomene und die pragmatische Komponente des Koreanischen. Tübingen: Gunter Narr Verlag.

Lenz, Michael. 2011. “ Surabaya auf Ostjava: Das alte Lied vom Schuft.” Spiegel Online. http:/ / www.spiegel.de/reise/fernweh/surabaya-auf-ostjava-das-alte-liedvom-schuft-a-769076.html

Lestari, Wahyu P. 2012. Perbedaan dialektis bahasa Jawa di Kecamatan Umbulsari Kabupaten Jember dengan Bahasa Jawa Baku. Thesis, Jember: Universitas Jember.

Mardjana. 1933. Lajang isi kawroeh bab basa Djawa sawetara. Groningen; The Hague; Batavia: J. B. Wolters' Uitgevers-Maatschappij.

Martin, Samuel E. 1964. "Speech Levels in Japan and Korea." Pp. 407-415 in Language in Culture and Society: A Reader in Linguistics and Anthropology. New York: Harper \& Row.

Mas Moeljono, Koentjahjo, Leo I. Ardiana, E. S. P. Tampoebolon, and Sri W. Widayati. 1986. Tingkat tutur Bahasa Jawa dialek Banyuwangi. Jakarta: Pusat Pembinaan dan Pengembangan Bahasa, Departemen Pendidikan dan Kebudayaan. 
Mujianto, Widodo H. S., Sunaryo H. S., and Taufik Dermawan. 1990. Penelitian karakterisasi bahasa ludruk di Jawa Timur. Jakarta: Departemen Pendidikan dan Kebudayaan.

Nothofer, Bernd. 1975. “The reconstruction of Proto-Malayo-Javanic.” Verhandelingen van het Koninklijk Instituut voor Taal-, Land-en Volkenkunde.

https://www.jstor.org/stable/27863392

Nothofer, Bernd. 1980. Dialektgeographische Untersuchungen in West-Java und im westlichen Zentraljava. Wiesbaden: Harrassowitz.

Nothofer, Bernd. 1981. Dialektatlas von Zentral-Java. Wiesbaden: Otto Harrassowitz.

Nothofer, Bernd. 1985. "The Subgrouping of the Languages of the Javo-Sumatra Hesion: A Reconsideration." Bijdragen tot de Taal-, Land- en Volkenkunde 141(2/3):288302. https://www.jstor.org/stable/27863679

Oetomo, Dede 1988. “Bahasa rahasia waria dan gay di Surabaya.” in [Makalah] Seminar Sosiolinguistik II. Depok: Universitas Indonesia.

Ogloblin, Alexander K. 2005. “Javanese.” Pp. 590-624 in The Austronesian languages of Asia and Madagascar, edited by Alexander Adelaar and Nikolaus P. Himmelmann. $1^{\text {st }}$ ed. London; New York: Routledge Taylor \& Francis Group.

Pigeaud, Thedoor G. T. 1967. Literature of Java: Catalogue Raisonné of Javanese Manuscripts in the Library of the University of Leiden and Other Public Collections in the Netherlands. Volume I: Synopsis of Javanese Literature 900-1900 A.D. The Hague; Leiden: Nyhoff; Bibliotheca Universitatis.

Poedjosoedarmo, Soepomo, Th. Kundjana, Gloria Soepomo, and Alip Suharso. 1979. Tingkat tutur bahasa Jawa. Jakarta: Pusat Pembinaan dan Pengembangan Bahasa, Departemen Pendidikan dan Kebudayaan.

Poerwadarminta, W. J. S., C. S. Hardjasoedarma, and J. Chr. Poedjasoedira. 1939. Baoesastra Djawa. Batavia: J. B. Wolters' Uitgevers-Maatschappij N. V. Groningen.

Prijanggana, M. S. 1957. "Sedikit tentang Bahasa Banjuwangi." Bahasa dan Budaja 2:32-36.

Rafferty, Ellen. 1984. "Languages of the Chinese of Java - An Historical Review." Journal of Asian Studies 43(2):247-272. https:/ / www.jstor.org/stable/2055313

Robson, Stuart and Singgih Wibisono. 2002. Javanese English Dictionary. Hong Kong: Periplus Editions (HK).

Roorda, Toca. 1855. Javaansche Grammatica: Benevens een leesboek tot oefening in de Javaansche taal. Eerste deel: Grammatica. Amsterdam: Johannes Müller.

Ross, Malcolm 1995. "Some current issues in Austronesian linguistics." Pp. 45-120 in Comparative Austronesian Dictionary: An Introduction to Austronesian Studies. Volume 1. Part 1: Fascicle 1, edited by Darrell T. Tryon. Berlin; New York: Mouton de Gruyter.

Rouf, Irwan and Shenia Ananda. 2013. Rangkuman 100 Cerita Rakyat Indonesia: Dari Sabang Sampai Merauke. Jakarta: Anak Kita. 
Sariono, Agus. 2002. Bahasa dan sastra Using: Ragam dan alternatif kajian. Jember: Penerbit Tapal Kuda, Universitas Jember.

Schulz von Thun, Friedemann. 1981. Miteinander reden 1: Störungen und Klärungen. Allgemeine Psychologie der Kommunikation. Reinbek: Rowohlt.

Setyowati, Sri. 2004. Donga kembang Waru. Malang: Komunitas Cantrik.

Siwidana. 2004. “Empal brewok made in Pojok Kampung.” Jaya Baya, pp. 28-29.

Smith-Hefner, Nancy J. 1983. Language and social identity: speaking Javanese in Tengger. Dissertation. Ann Arbor: University of Michigan.

Smith-Hefner, Nancy J. 1988. “Cara Tengger: notes on a non-standard dialect of Javanese." Pp. 203-233 in Studies In Austronesian linguistics. $7^{\text {th }}$ ed. Athens, Ohio: Ohio University Center for International Studies, Center for Southeast Asian Studies.

Soediro, M. 1932. Dialek van Banjoewangi; uitgewerkte woordenlijsten; SKBW 1-4. Yogyakarta.

Soedjiatno, Dwi Saksomo, M. A. Latief, and M. Moehnilabib. 1984. Kata Tugas Bahasa Jawa Dialek Jawa Timur. Jakarta, Pusat Pembinaan dan Pengembangan Bahasa, Departemen Pendidikan dan Kebudayaan.

Soedjito, Mansur Hasan, Ida Lestari, and I. L. M. Oetama. 1985. Morfologi kata kerja Bahasa Jawa dialek Tengger. Proyek Penelitian Bahasa dan Sastra Indonesia dan Daerah Jawa Timur, Departemen Pendidikan dan Kebudayaan.

Soedjito, Abdul S. Ibrahim, I. L. M. Oetama, and Imam Hanafi. 1981. Sistem morfologi kata kerja bahasa Jawa dialek Jawa Timur. Jakarta: Pusat Pembinaan dan Pengembangan Bahasa, Departemen Pendidikan dan Kebudayaan.

Soedjito, Sri Soedarman, Basennang Seliwangi, Joeswotomo, and I. L. M. Oetama. 1985. Sistem perulangan bahasa Jawa dialek Jawa Timur. Jakarta: Pusat Pembinaan dan Pengembangan Bahasa, Departemen Pendidikan dan Kebudayaan.

Soedjito, Sri Soedarman, Sunaryo H. S., Solchan T. W., Dwi Saksomo, Imam Machfudz, and Subandi Djajengwasito. 1986. Pemakaian Bahasa Jawa di Pesisir Utara Jawa Timur bagian sempit. Jakarta: Pusat Pembinaan dan Pengembangan Bahasa, Departemen Pendidikan dan Kebudayaan.

Soedjito, Sunoto, I. L. M. Oetama, Abdul R. H. A., and Mansur Hasan. 1984. Struktur bahasa Jawa dialek Tengger. Jakarta: Pusat Pembinaan dan Pengembangan Bahasa, Departemen Pendidikan dan Kebudayaan.

Soegianto 1982. “Dialek Bahasa Jawa-Gresik.” Pp. 1-11 in Linguistik dan Bahasa Indonesia (Kumpulan makalah seminar linguistik 1982). Buku ke II. Surakarta : Masyarakat Linguistik Indonesia dan Universitas Sebelas Maret.

Soenarno, Adi. 2011. Kamus bahasa Malangan: osob kiwalan (boso walikan), bahasa "kebalikan" Malang, bahasa Malang (osob ngalam). Wagir: Bayumedia Pub. 
Soepomo and Th. Koendjono. 1976/1977. Unda-Usuk Bahasa Jawa: Laporan Penelitian Fakultas Keguruan Sastra dan Seni IKIP Sanata Dharma Yogyakarta. Jakarta: Pusat Pembinaan dan Pengembangan Bahasa, Departemen Pendidikan dan Kebudayaan.

Soetoko, Soekarto, Abd. R. Z., Busyairi, and Hadiri. 1981. Geografi Dialek Banyuwangi. Jakarta: Pusat Pembinaan dan Pengembangan Bahasa, Departmen Pendidikan dan Kebudayaan.

Soetoko, Soegianto, Sodaqoh Z., and Ayu Soetarto. 1984. Geografi dialek Bahasa Jawa di kabupaten Surabaya. Jakarta: Pusat Pembinaan dan Pengembangan Bahasa, Departemen Pendidikan dan Kebudayaan.

Sri Budi Astuti. 1986. Kata ganti Bahasa Jawa dialek Surabaya. Thesis, Jember: Fakultas Sastra, Universitas Jember.

Srijono. 1976. “Ngungak Basa Jawi Surabayan. Kusir² Surabaya sedaya tiyang sae." Jaya Baya, pp. 27-30.

Sudarwati. 1987. Ragam bahasa remaja di kotamadya Malang. Thesis, Jember: Fakultas Sastra, Universitas Jember.

Suharto. 1983. "Bahasa walikan malang tidak lagi bersifat rahasia." Sinar Harapan, August 9.

Sunaryo, H. S., Oscar Rusmandji, I. L. M. Oetama, Ali Saukah, and Soesono Kartomiharjo. 1984. Geografi Dialek Bahasa Jawa di Kabupaten Tuban. Jakarta: Pusat Pembinaan dan Pengembangan Bahasa, Departemen Pendidikan dan Kebudayaan.

Sunoto, Sunaryo H. S., M. H. Sudirah, and E. Sadtono. 1990. Sistem derivasi dan infleksi Bahasa Jawa dialek Tengger. Jakarta: Departemen Pendidikan dan Kebudayaan.

Supriyanto, Yayan. 2017. "Cak Dave, Bule Australia yang Peduli Bahasa Jawa." NET.Z. https://netz.id/news/2017/03/27/00316/1007230317/cak-dave-buleaustralia-yang-peduli-bahasa-jawa

Sutoko, Soekarto, Yoseph Supardjana, Soetarto, and I. C. Sujarwadi. 1985. Geografi bahasa Jawa dialek Tengger. Proyek Penelitian Bahasa dan Sastra Indonesia dan Daerah Jawa Timur, Departemen Pendidikan dan Kebudayaan.

Timoer, Soenarto. 1983. Menjelajahi Jama Bahari Indonesia. Mitos Çūra-Bhaya: Cerita rakyat sebagai sumber penelitian sejarah Surabaya. Jakarta: Balai Pustaka.

Uhlenbeck, E. M. 1950. De tegenstelling Krama:Ngoko: Haar positie in het Javaanse Taalsysteem. Groningen: J. B. Wolters.

Uhlenbeck, E. M. 1964. A Critical Survey of Studies on the Languages of Java and Madura. The Hague: Martinus Nijhoff.

Van Hinloopen Labberton, D. 1900. Het Javaansch van Malang-Pasoeroehan. Batavia; The Hague: Albrecht; M. Nijhoff.

Wáng Shū Rèn 王叔任. 1987. Yìndùníxīyà gǔdài shǐ E卬度尼西亚古代史 [Indonesia's History]. Beijing: Zhōngguó shèhuì kēxué chūbăn shè 中国社会科学出版社 [China Social Sciences Press]. 
Widodo, Dukut I. 2006. “Osob Kiwalan.” Pp. 165-172 in Malang tempo doeloe. Djilid doea. Malang: Bayumedia Publishing.

Winter, C. F. 1848. Javaansche zamenspraken. Eerste deel: Zamenspraken over verschillende onderwerpen. Amsterdam: Johannes Müller.

Winter, C. F. 1858. Javaansche zamenspraken. Tweede deel: Zamenspraken over salokas, paribasans, wangsalans en andere onderwerpen. Amsterdam: Johannes Müller.

Wolff, John U. and Soepomo Poedjosoedarmo. 1982. Communicative Codes in Central Java. Ithaca: Cornell University.

Yannuar, Nurenzia, Emalia Iragiliati, and Evynurul L. Zen. 2017. “Bòsò Walikan Malang's Address Practices." GEMA Online® Journal of Language Studies 17(1):107123. http:// doi.org/10.17576/gema-2017-1701-07

Yulianto, Bambang. 2010. Penggunaan cara walikan dalam bahasa Jawa dialek Tuban: Kajian fonologi generatif. Laporan penelitian fundamental lanjutan. Surabaya:

Kementerian Pendidikan Nasional, Republik Indonesia, Universitas Negeri Surabaya, Lembaga Penelitian.

Zoetmulder, Petrus J. 1982. Old Javanese-English dictionary. The Hague: Nijhoff. 